\title{
Review
}

\section{TOXICOLOGICAL CORRELATION BETWEEN CHANGES IN BLOOD BIOCHEMICAL PARAMETERS AND LIVER HISTOPATHOLOGICAL FINDINGS}

\author{
Toshiyuki FUJII \\ Toxicology Research Laboratories, \\ Fujisawa Pharmaceutical Co., Ltd., \\ 1-6, 2-chome, Kashima, Yodogawa-ku, Osaka 532, Japan
}

(Received March 14, 1997; Accepted June 16, 1997)

\begin{abstract}
The toxicological correlation between blood biochemical parameters and liver histopathological findings was summarized mainly in rats and dogs on the basis of our experiments and published papers. In rats and dogs with hepatocytic necrosis, GPT and GOT increased with a good correlation to necrotic severity. In dogs with cholestasis, ALP, $\gamma$-GTP, T.BIL and BSP retention rates increased. In mixed types of hepatitis or cholestasis and hepatic necrosis, GPT, GOT and ALP increased in rats and dogs and additionally $\gamma$-GTP and BSP retention rates increased in dogs. In hepatic steatosis, CHOL and TRIG decreased in rats and dogs. In hepatic injury due to accumulation of foreign materials or cell compornents and sinusoidal cell injury, no specific correlation with biochemical parameters was noted.
\end{abstract}

KEY WORDS : Biochemical parameters, Histopathological findings, Liver

\section{INTRODUCTION}

Drugs given to the body are detoxicated mostly in the liver and excreted. The liver is thus a main target organ in toxicity studies in which the toxic changes of various drugs are manifested. For the diagnosis of hepatotoxicity, blood biochemical parameters and histopathology are useful measures, and a correct understanding of the correlation between blood biochemical changes and histopathological findings in the liver is important for a drug's toxic evaluation. On the other hand, the majority of toxic reports only cite the values of blood biochemical parameters at the conclusion of dosing and histopathological findings by light microscopy. Moreover, these correlations are not discussed

Correspondence : Toshiyuki FUJII at the above address. collectively. The present report is summarized from our experiments and published papers on the correlation between various histopathological changes of hepatotoxicity and blood biochemical parameters used for diagnosis of liver injury in experimental animals (mainly rats and dogs) given compounds undergoing development as drugs. Histopathological findings similar to those classified by pathologic morphology of the liver in humans were selected mainly in this report, along with those which were of special histopathological interest. Blood biochemical parameters were selected from reports on rats (Leonard et al., 1984; Carakostas et al., 1986; Carakostas et al., 1990), dogs (Leissing et al., 1985; Uchimaya et al., 1985), various other experimental animals (Dooley, 1979; Wolford et al., 1986) and humans (Orentreich et al., 1965). For classification of pathologic morphology, we 
referred to reports (Smetana, 1963; Popper et al., 1965) and textbooks (Zimmerman, 1979; Kanel et al., 1992; Klatskin et al., 1993) describing toxic or allergic liver injury inflicted by drugs.

\section{Types of hepatocyte injury}

\section{Acute hepatocytic necrosis}

In a male rat given compound A-1 orally (p.o.) for 14 days, 2 to 3 -fold increases in GPT (154 mU/ml), GOT $(155 \mathrm{mU} / \mathrm{ml})$ and ALP (814 $\mathrm{mU} / \mathrm{ml}$ ) and about a 50\% decrease in TRIG (61 $\mathrm{mg} / \mathrm{dl}$ ), and blood biochemical parameters in a male dog given compound $\mathrm{N}-1$ intravenously (i.v.) for 3 days are shown in Table 1. Marked increases in GPT, GOT, LDH and T.BIL, a several-fold increase in ALP and decreases in CHOL and TRIG were observed. Microscopically, there was broad necrosis of the centrilobular hepatocytes with hemorrhage and hepatocyte vacuolation around the area (Photo. 1), although the severity differed between rats and dogs.

The following reports showed similar changes: increases in GOT, ALP, LDH and T.BIL and centrilobular hepatocytic necrosis in rats given various cephalosporin derivatives once subcutaneously (s.c.) (Tsuchiya et al., 1976); marked increase in GPT, about a $50 \%$ decrease in CHOL and various levels of cen-

Table 1. Blood biochemical parameters in 1 male dog (No.11655) given compound N-1 i.v. for 3 days.

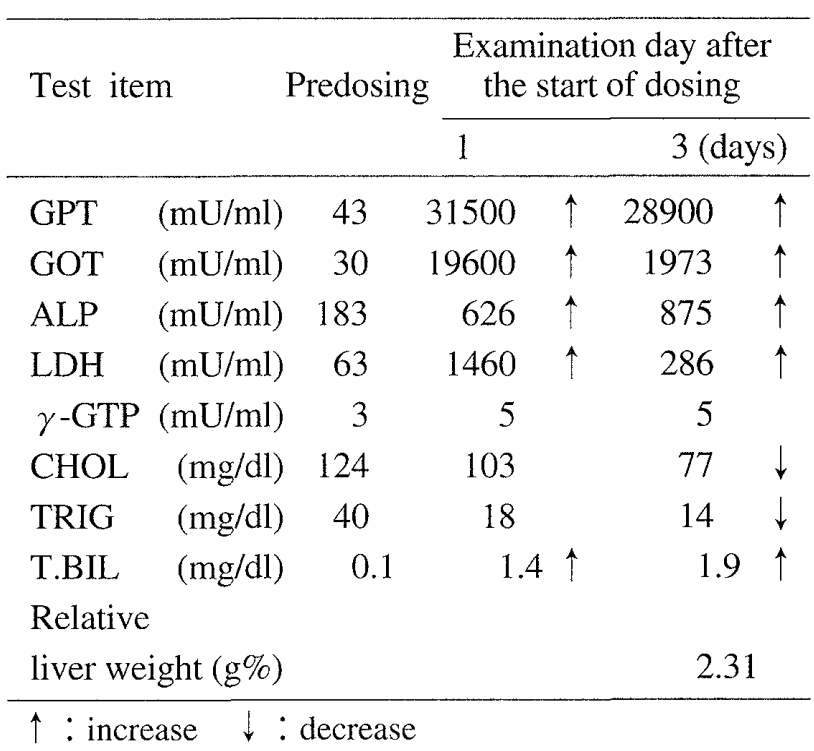

trilobular hepatocytic necrosis (Francavilla et al., 1988) or marked increases in GPT, centrilobular hepatocytic necrosis and hemorrhage (Francavilla et al., 1989; Panella et al., 1990) in dogs given acetaminophen once or several times s.c.; dose-dependent increases in GPT and GOT and broad necrosis of the hepatocytes in rats given diethyldithiocarbamate (Ishiyama et al., 1990) or loxistatin once (Fukushima et al., 1990); an increase in GPT and hepatocytic necrosis in mice given methylphenidate once intraperitoneally (i.p.) (Roberts et al., 1994); a marked increase in GPT and hepatocytic necrosis in phenobarbitone-pretreated rats given halothane by inhalation (Knights et al., 1987); and an increase in GOT and centrilobular hepatocytic necrosis in ethanol- or isopentanol-pretreated rats given acetaminophen p.o. (Kostrubsky et al., 1995).

\section{Subacute hepatocytic necrosis}

In a male rat given compound M-1 i.v. for 28 days, 2 to 3 -fold increases in GPT (122 $\mathrm{mU} / \mathrm{ml})$ and GOT $(144 \mathrm{mU} / \mathrm{ml})$ were observed. Table 2 shows blood biochemical parameters in a male dog given compound M-2 i.v. for 28 days. Two to three-fold increases in GOT, ALP and T.BIL, a marked increase in $\gamma$-GTP, an increase in BSP retention rate, a decrease in TRIG and a marked decrease in GPT were

Table 2. Blood biochemical parameters in 1 male dog (No.16551) given compound M-2 i.v. for 28 days.

\begin{tabular}{|c|c|c|c|c|c|}
\hline \multirow[t]{2}{*}{ Test item } & \multirow[t]{2}{*}{ Predosing } & \multicolumn{4}{|c|}{$\begin{array}{l}\text { Examination day after } \\
\text { the start of dosing }\end{array}$} \\
\hline & & 14 & & 28 (day & \\
\hline$(\mathrm{mU} / \mathrm{ml})$ & 48 & 4 & $\downarrow$ & 6 & $\downarrow$ \\
\hline$(\mathrm{mU} / \mathrm{ml})$ & 30 & 30 & & 132 & $\uparrow$ \\
\hline$(\mathrm{mU} / \mathrm{ml})$ & 171 & 166 & & 306 & $\uparrow$ \\
\hline$(\mathrm{mU} / \mathrm{ml})$ & 141 & 206 & & 193 & \\
\hline$\gamma-\mathrm{GTP}(\mathrm{mU} / \mathrm{ml})$ & 3 & 6 & & 29 & $\uparrow$ \\
\hline $\mathrm{CHOL} \quad(\mathrm{mg} / \mathrm{dl})$ & 133 & 181 & & 219 & \\
\hline$(\mathrm{mg} / \mathrm{dl})$ & 42 & 19 & $\downarrow$ & 16 & $\downarrow$ \\
\hline$(\mathrm{mg} / \mathrm{dl})$ & 0.1 & 0.1 & & 0.3 & $\uparrow$ \\
\hline BSP & 3.4 & & & 17.7 & $\uparrow$ \\
\hline \multicolumn{6}{|l|}{ Relative } \\
\hline liver weight ( $\mathrm{g} \%$ ) & & & & 3.31 & \\
\hline
\end{tabular}


observed. Microscopically, there were focal centrilobular necrosis of the hepatocytes, slight inflammatory cell infiltration and proliferation of the bile duct in rats and dogs, and on electron microscopic observation of the necrosis in dogs, there were deformity of the nucleus, increased density of the cytoplasm, dilatation of the endoplasmic reticulum, swelling of the mitochondria (Photo. 2) and appearance of giant mitochondria.

Similar changes have been reported as follows: an increase in GOT and hepatocytic necrosis in rats given sodium valproate i.p. for 21 days (Cotariu et al., 1987); an increase in GPT and focal hepatocytic necrosis in rats given halothane (Plummer et al., 1983) or methoxyflurane (Plummer et al., 1985) by inhalation for about 90 days; an increase in GPT and single cell necrosis of the liver in rats given cyclosporin A p.o. dose for 90 days (Ryffel et al., 1983); and increases in GPT, GOT, $\gamma$-GTP and T.BIL, appearance of polynucleated hepatocytes and single cell necrosis in rats given ABT987 p.o. for 30 days, along with increases in GPT, GOT, ALP, $\gamma$-GPT and T.BIL, hepatic steatosis and necrosis and proliferation of the bile duct in dogs given the drug p.o. for the same period. (Yang et al., 1995).

Generally, when hepatocytic necrosis is observed histopathologically, the extent of the lesion is proportional to the severity of the

Table 3. Blood biochemical parameters in 1 female dog (No.17486) given compound A-2 p.o. for 14 days.

\begin{tabular}{|c|c|c|c|c|c|}
\hline \multirow[t]{2}{*}{ Test item } & \multirow[t]{2}{*}{ Predosing } & \multicolumn{4}{|c|}{$\begin{array}{l}\text { Examination day after } \\
\text { the start of dosing }\end{array}$} \\
\hline & & 7 & & 14 (days) & \\
\hline$(\mathrm{mU} / \mathrm{ml})$ & 37 & 66 & $\uparrow$ & 65 & $\uparrow$ \\
\hline$(\mathrm{mU} / \mathrm{ml})$ & 30 & 32 & & 50 & $\uparrow$ \\
\hline ALP $\quad(\mathrm{mU} / \mathrm{ml})$ & 169 & 347 & $\uparrow$ & 946 & $\uparrow$ \\
\hline$\gamma-\mathrm{GTP}(\mathrm{mU} / \mathrm{ml})$ & 4 & 8 & & 65 & $\uparrow$ \\
\hline $\mathrm{CHOL} \quad(\mathrm{mg} / \mathrm{dl})$ & 174 & 248 & $\uparrow$ & 343 & \\
\hline TRIG (mg/dl) & 46 & 81 & $\uparrow$ & 47 & \\
\hline T.BIL $\quad(\mathrm{mg} / \mathrm{dl})$ & 0.1 & 0.2 & & 4.3 & 1 \\
\hline BSP & 2.1 & 10.4 & $\uparrow$ & 11.0 & $\uparrow$ \\
\hline \multicolumn{6}{|l|}{ Relative } \\
\hline liver weight ( $\mathrm{g} \%$ ) & & & & 4.37 & \\
\hline
\end{tabular}

increase in GPT and GOT values. However, GPT decreased in some cases and GOP only increased, although acute or subacute hepatic necrosis was observed. A decrease in GPT has been reported in rats (Matsubara et al., 1979; Dhami et al., 1979), dogs (Kobayashi et al., 1980) and monkeys (Suzuki et al., 1983) given antibiotics i.v. or s.c., though the effects on the liver were unknown. ALP also tended to increase in rats and dogs, and the necrotic areas were also proportional to the increased ALP values. T.BIL increased in dogs similarly. Although increases in T.BIL and BSP retention rate were observed in dogs, cholestasis was not observed. The changes were ascribed to a dysfunction of bile production and constriction of the bile ducts in the liver induced by hepatocytic necrosis. As other changes, increased LDH and decreased TRIG were common in the animals with hepatic necrosis.

\section{Types of cholestasis}

\section{Acute cholestasis}

Blood biochemical parameters in a female dog given compound A-2 p.o. for 14 days are shown in Table 3. Marked increases in ALP, $\gamma$-GTP and T.BIL, about 2-fold increases in GPT, GOT, CHOL and increases in BSP retention rate and relative liver weight were observed.

Table 4. Blood biochemical parameters in 1 male dog (No.1087 I) given compound D-1 p.o. for 90 days.

\begin{tabular}{|c|c|c|c|c|c|}
\hline \multirow{2}{*}{\multicolumn{2}{|c|}{ Test item }} & \multirow[t]{2}{*}{ Predosing } & \multicolumn{3}{|c|}{$\begin{array}{l}\text { Examination day after } \\
\text { the start of dosing }\end{array}$} \\
\hline & & & 14 & 35 & $\begin{array}{c}90 \\
\text { (days) }\end{array}$ \\
\hline GPT & $(\mathrm{mU} / \mathrm{ml})$ & 43 & 48 & 46 & 50 \\
\hline GOT & $(\mathrm{mU} / \mathrm{ml})$ & 23 & 27 & 28 & 27 \\
\hline ALP & $(\mathrm{mU} / \mathrm{ml})$ & 189 & 214 & 221 & $330 \uparrow$ \\
\hline $\mathrm{LDH}$ & $(\mathrm{mU} / \mathrm{ml})$ & 65 & 58 & 76 & 59 \\
\hline$\gamma$-GTP & $(\mathrm{mU} / \mathrm{ml})$ & 2 & 2 & 3 & $10 \uparrow$ \\
\hline CHOL & $(\mathrm{mg} / \mathrm{dl})$ & 166 & 133 & 258 & $327 \uparrow$ \\
\hline TRIG & $(\mathrm{mg} / \mathrm{dl})$ & 74 & 84 & 96 & 72 \\
\hline T.BIL & $(\mathrm{mg} / \mathrm{dl})$ & 0.1 & 0.1 & 0.1 & $0.2 \uparrow$ \\
\hline BSP & $(\%)$ & 3.1 & & $11.7 \uparrow$ & $10.6 \uparrow$ \\
\hline \multicolumn{6}{|c|}{ Relative } \\
\hline \multicolumn{3}{|c|}{ liver weight $(\mathrm{g} \%)$} & & & 3.03 \\
\hline
\end{tabular}


Microscopically, there were no remarkable changes, but on electron microscopical observation, there were degeneration of the cristae in the mitochondria, enlargement of Golgi's apparatus, slight dilatation of the bile capillary, shortening or disappearance of the microvilli and cholestasis (Photo. 3). Cholestasis was also observed in the rat liver perfused with estradiol-17 $\beta$-D-glucuronide, chlorpromazine or $\alpha$-naphthylisothiocyanate (Abernathy et al., 1992; Krell et al., 1987).

\section{Subacute cholestasis}

Blood biochemical parameters in a male dog given compound D-1 p.o. for 90 days are shown in Table 4.

Slight increases in ALP, $\gamma$-GTP, CHOL and T.BIL and increased BSP retention rate were observed in this study. Microscopically, there were no abnormal changes in the hepatocytes, but yellowish brown bile plugs were observed in the bile capillary (Photo. 4). By electron microscopy, dilatation of the capillary, disappearance of the microvilli, an increase in the microfilament around the bile capillary and cholestasis were observed in the biliary system, and increased lysosomes or bile pigment deposits in the hepatocytes as well as activated Kupffer cells in the sinusoids were also observed.

Although we have not found cholestasis in rats with increased ALP, T.BIL and/or relative liver weight, increased T.BIL and cholestasis (Redmond et al., 1971), and increases in T.BIL and GPT along with cholestasis (Drew et al., 1976) have been observed in rats given $\alpha$-naphthylisothiocyanate once p.o. However, such changes were noted only in a few reports and only by single dosing. On the other hand, increases in ALP, CHOL and BSP retention rate and enlargement of the hepatocytes and cholestasis in the bile capillary were observed in dogs given diazepam p.o. for 28 days or given prazepam p.o. for 30 days (Owen et al., 1970; Kakishita et al., 1978). Increases in ALP, CHOL, TRIG, T.BIL and BSP retention rate, enlargement of the hepatocytes, bile pigment deposits in the hepatocytes and bile plugs in the bile capillary were observed in dogs given $\mathrm{KB}$ 509 p.o. for 90 days (Unno et al., 1980). When cholestasis was observed histopathologically, ALP, $\gamma$-GTP, T.BIL and BSP retention rate increased in blood biochemical parameters, although the values differed by time course and severity of bile retention. Since ALP decreases markedly in rats and dogs as they grow older, the changes of ALP values should be regarded with care in long-term repeated dose toxicity studies.

\section{Mixed types of liver injury (hepatocytic necro- sis with hepatitis and cholestasis) \\ Acute mixed types}

Blood biochemical parameters in a male dog given compound A-3 p.o. for 14 days are shown in Table 5. Marked increases in GPT, ALP, $\gamma$-GTP and BSP retention rate and slight to moderate increases in GOT and CHOL were observed, and moderate increases in GPT (585 $\mathrm{mU} / \mathrm{ml})$, GOT (270 mU/ml), ALP (472 mU/ml), $\gamma-\mathrm{GTP}(8 \mathrm{mU} / \mathrm{ml})$ and $\mathrm{BSP}$ retention rate $(10.7 \%)$ were seen in a female dog given D-2 p.o. for 14 days. Microscopically, focal hepatocytic necrosis, inflammatory cell infiltration and dilatation of the bile duct were observed in dogs given either compound (Photo. 5), and by electron microscopy there were degeneration of the hepatocytes and nuclei, swelling and deformity of the mitochondria, giant mitochondria, bile pigment deposits in the hepatocytes and slight

Table 5. Blood biochemical parameters in 1 male dog (No.17319) given compound A-3 p.o. for 14 days.

\begin{tabular}{|c|c|c|c|c|c|}
\hline \multirow[t]{2}{*}{ Test item } & \multirow[t]{2}{*}{ Predosing } & \multicolumn{4}{|c|}{$\begin{array}{l}\text { Examination day after } \\
\text { the start of dosing }\end{array}$} \\
\hline & & 7 & & 14 (day & \\
\hline$(\mathrm{mU} / \mathrm{ml})$ & 48 & 2730 & $\uparrow$ & 1822 & $\uparrow$ \\
\hline$(\mathrm{mU} / \mathrm{ml})$ & 31 & 116 & $\uparrow$ & 162 & \\
\hline$(\mathrm{mU} / \mathrm{ml})$ & 154 & 1242 & $\uparrow$ & 1564 & $\uparrow$ \\
\hline$(\mathrm{mU} / \mathrm{ml})$ & 107 & 101 & & 155 & \\
\hline$\gamma-\mathrm{GTP}(\mathrm{mU} / \mathrm{ml})$ & 4 & 48 & $\uparrow$ & 32 & \\
\hline $\mathrm{CHOL} \quad(\mathrm{mg} / \mathrm{dl})$ & 128 & 254 & $\uparrow$ & 201 & \\
\hline$(\mathrm{mg} / \mathrm{dl})$ & 36 & 40 & & 29 & \\
\hline$(\mathrm{mg} / \mathrm{dl})$ & 0.1 & 0.1 & & 0.2 & \\
\hline BSP & 2.8 & & & 11.8 & \\
\hline \multicolumn{6}{|l|}{ Relative } \\
\hline liver weight $(\mathrm{g} \%)$ & & & & 3.1 & \\
\hline
\end{tabular}


dilatation of the bile capillary.

\section{Subacute mixed types}

Blood biochemical parameters in male rats given compound A-4 p.o. for 90 days are shown in Table 6. Moderate increases in GPT and GOT and slight increases in ALP and $\gamma$-GTP were observed, and moderate increases in GPT $(585 \mathrm{mU} / \mathrm{ml})$, GOT $(270 \mathrm{mU} / \mathrm{ml})$, ALP (748 $\mathrm{mU} / \mathrm{ml}), \gamma$-GTP $(9 \mathrm{mU} / \mathrm{ml})$, T.BIL $(0.5 \mathrm{mg} / \mathrm{dl})$ and BSP retention rate $(16.4 \%)$ were seen in a male dog given compound D-3 p.o. for 90 days. Microscopically, there were focal hepatocytic necrosis or single cell necrosis and inflammatory cell infiltration in rats and dogs, proliferation of the bile duct in rats and dilatation of the sinusoids in dogs. Additionally, there were bile pigment deposits in the hepatocytes and slight dilatation of the bile capillary (Photo. 6) by electron microscopy.

The citation "Mixed types" has not been used for drug-induced hepatic injury in rats and dogs. However, when we examined the livers of dogs histopathologically in detail, we frequently found hepatocytic necrosis with inflammatory cell infiltration, bile pigment deposits in the hepatocytes or slight dilatation of the bile capillaries and cholestasis, while blood chemical changes showed mixed types of hepatocytic necrosis and cholestasis. Therefore, we provid-

Table 6. Blood biochemical parameters in male rats given compound A-4 p.o. for 90 days.

\begin{tabular}{|c|c|c|c|c|c|}
\hline \multirow{2}{*}{\multicolumn{2}{|c|}{ Test item }} & \multirow{2}{*}{$\begin{array}{c}\text { Mean Value } \\
\text { of controls }\end{array}$} & \multicolumn{3}{|c|}{$\begin{array}{l}\text { Examination day after } \\
\text { the start of dosing }\end{array}$} \\
\hline & & & 7 & 14 & $\begin{array}{c}90 \\
\text { (days) }\end{array}$ \\
\hline GPT & $(\mathrm{mU} / \mathrm{ml})$ & 49 & $275 \uparrow$ & $154 \uparrow$ & $137 \uparrow$ \\
\hline GOT & $(\mathrm{mU} / \mathrm{ml})$ & 67 & $274 \uparrow$ & $155 \uparrow$ & $136 \uparrow$ \\
\hline ALP & $(\mathrm{mU} / \mathrm{ml})$ & 354 & $547 \uparrow$ & $514 \uparrow$ & 370 \\
\hline $\mathrm{LDH}$ & $(\mathrm{mU} / \mathrm{ml})$ & 171 & 193 & 149 & 148 \\
\hline$\gamma$-GTP & $(\mathrm{mU} / \mathrm{ml})$ & 1 & 3 & $5 \uparrow$ & 1 \\
\hline CHOL & $(\mathrm{mg} / \mathrm{dl})$ & 62 & 68 & 68 & 68 \\
\hline TRIG & $(\mathrm{mg} / \mathrm{dl})$ & 121 & 100 & 61 & 115 \\
\hline T.BIL & $(\mathrm{mg} / \mathrm{dl})$ & 0.1 & 0.1 & 0.1 & 0.1 \\
\hline \multicolumn{6}{|c|}{ Relative } \\
\hline liver we & $\operatorname{ght}(\mathrm{g} \%)$ & 3.92 & 4.67 & 4.84 & 3.70 \\
\hline
\end{tabular}

ed "Mixed types" in this report.

In the mixed types, the main blood biochemical parameters were increases in GTP, GOT and ALP in rats and dogs, and these changes were mostly accompanied by increases in $\gamma$-GTP and BSP retention rate in dogs.

\section{Hepatic steatosis}

\section{Acute hepatic steatosis}

Blood biochemical parameters in a male rat given compound B-1 i.v. for 4 days are shown in Table 7. Slight decreases in CHOL and TRIG and slight increases in GOT, ALP and LDH were observed. Microscopically, diffused small and large vacuoles were observed in the liver (Photo. 7a), and numerous fatty droplets (Photo. $7 b)$ by Oil red $\mathrm{O}$ staining. Electron microscopically, fatty droplets were observed in the nucleus as well as in the cytoplasm (Photo. 8).

Fatty droplets in the hepatocytes were observed from 6 hours after dosing in rats given tetracycline i.p. once or for several days, and the number and size of the droplets increased with time (Gray et al., 1974). Other reports were as follows: an increase in GOT and fatty droplets by microscopy and electron microscopy were observed in rats given tetracycline i.p. for 3 or 4 days (Shauer et al., 1974); fatty liver and transient decreases in blood CHOL and phospholipids in mice given rolitetracycline once i.v. (Estler et al., 1980); and no changes in GPT or

Table 7. Blood biochemical parameters in 1 male rat given compound B-1 i.v. for 4 days.

\begin{tabular}{|c|c|c|c|c|c|}
\hline \multirow[t]{2}{*}{ Test item } & \multirow{2}{*}{$\begin{array}{l}\text { Predosing } \\
\text { of controls }\end{array}$} & \multicolumn{4}{|c|}{$\begin{array}{l}\text { Examination day after } \\
\text { the start of dosing }\end{array}$} \\
\hline & & 1 & & 4 (days) & \\
\hline$(\mathrm{mU} / \mathrm{ml})$ & 31 & 38 & & 50 & \\
\hline$(\mathrm{mU} / \mathrm{ml})$ & 62 & 76 & & 114 & $\uparrow$ \\
\hline$(\mathrm{mU} / \mathrm{ml})$ & 462 & 779 & $\uparrow$ & 693 & $\uparrow$ \\
\hline$(\mathrm{mU} / \mathrm{ml})$ & 141 & 342 & $\uparrow$ & 620 & $\uparrow$ \\
\hline$\gamma$-GTP $(\mathrm{mU} / \mathrm{ml})$ & 1 & 1 & & 1 & \\
\hline $\mathrm{CHOL} \quad(\mathrm{mg} / \mathrm{dl})$ & 49 & 25 & & 22 & $\downarrow$ \\
\hline TRIG $\quad(\mathrm{mg} / \mathrm{dl})$ & 124 & 24 & $\downarrow$ & 17 & $\downarrow$ \\
\hline T.BIL $\quad(\mathrm{mg} / \mathrm{dl})$ & 0.1 & 0.1 & & 0.1 & \\
\hline \multicolumn{6}{|l|}{ Relative } \\
\hline liver weight $(\mathrm{g} \%)$ & 4.50 & & & 4.52 & \\
\hline
\end{tabular}


GOT, with diffused fatty droplets by microscopy and numerous fatty vacuoles in the hepatocytes by electron microscopy in rats given valpronic acid and its metabolites i.p. for several days (Kesterson et al., 1984).

\section{Subacute hepatic steatosis}

In rats and dogs given compound E-1 i.v. for 90 days, a very slight decrease was observed in CHOL $(36 \mathrm{mg} / \mathrm{dl})$ in a female rat and very slight decreases in CHOL $(94 \mathrm{mg} / \mathrm{dl})$ and TRIG $(27 \mathrm{mg} / \mathrm{dl})$ in a female dog. Microscopically, numerous fine vacuoles and a few large vacuoles were observed in rats and dogs, and focal fatty deposits in the liver of dogs by oil red $\mathrm{O}$ staining. Additionally, diffused fatty droplets were observed in the liver of rats by electron microscopy.

Slight increases in ALP and CHOL and fatty droplets in the hepatocytes were observed in rats given an antibacterial agent p.o. for 30 days (Sugawara et al., 1996).

Our results showed a tendency to $\mathrm{CHOL}$ decrease due to fatty change of the hepatocytes. However, there were no published reports with correlation between blood biochemical parameters and hepatocytic steatosis. Additionally, it is known that CHOL decreases in animals with severe hepatic injury.

\section{Accumulation-type hepatic injury}

Blood biochemical parameters in a female rat given compound M-3 i.v. for 14 days are

Table 8. Blood biochemical parameters in 1 female rat (No.62246) given compound M-3 i.v. for 14 days.

\begin{tabular}{|c|c|c|c|c|}
\hline \multicolumn{2}{|c|}{ Test item } & \multirow{2}{*}{$\begin{array}{c}\begin{array}{c}\text { Mean value } \\
\text { of controls }\end{array} \\
29\end{array}$} & \multicolumn{2}{|l|}{$\begin{array}{l}\text { Value } \\
\text { on day } 14\end{array}$} \\
\hline GPT & $(\mathrm{mU} / \mathrm{ml})$ & & 99 & $\uparrow$ \\
\hline GOT & $(\mathrm{mU} / \mathrm{ml})$ & 71 & 276 & $\uparrow$ \\
\hline ALP & $(\mathrm{mU} / \mathrm{ml})$ & 313 & 726 & $\uparrow$ \\
\hline $\mathrm{LDH}$ & $(\mathrm{mU} / \mathrm{ml})$ & 160 & 190 & \\
\hline $\mathrm{CHOL}$ & $(\mathrm{mg} / \mathrm{dl})$ & 74 & 117 & \\
\hline TRIG & $(\mathrm{mg} / \mathrm{dl})$ & 108 & 80 & \\
\hline T.BIL & $(\mathrm{mg} / \mathrm{dl})$ & 0.1 & 0.1 & \\
\hline \multicolumn{5}{|c|}{ Relative } \\
\hline liver $\mathrm{w}$ & ight $(\mathrm{g} \%)$ & 3.82 & 4.46 & \\
\hline
\end{tabular}

shown in Table 8. About 2-fold increases in GPT, GOT and ALP were observed. Microscopically, eosinophilic material (Photo. 9) in the hepatocytes was observed, and electron microscopically, numerous small myelin-like structures in autolysosomes were observed in the hepatocytes (Photo. 10) and Kupffer cells.

Increases in GPT and GOT and inclusion bodies with whorled membranes consisting of many membrane-like materials were observed in dogs given erythromycin p.o. for 30 days (Gray et al., 1971). Increased liver weight and many lamella bodies in the hepatocytes were observed by electron microscopy in mice given ketoconazole p.o. for 21 days (Whitehouse et al., 1994), and myeloid bodies in rats given amphiphilic drugs on electron microscopic observation in various studies (Hruban, 1984). Phospholipidosis is a general term for these findings and covers findings characteristic of many drugs (Hayashi et al., 1985).

In a male rat given compound E-2 p.o. for 28 days, there were no abnormal changes in blood biochemical parameters except decreased TRIG (49 mg/dl) due to pharmacological effects and a marked increase in relative liver weight. Microscopically, swollen and eosinophilic hepatocytes were observed, and electron microscopically, slight deformity of the mitochondria and

Table 9. Blood biochemical parameters in 1 male dog (No.10351) given compound C-1 p.o. for 28 days.

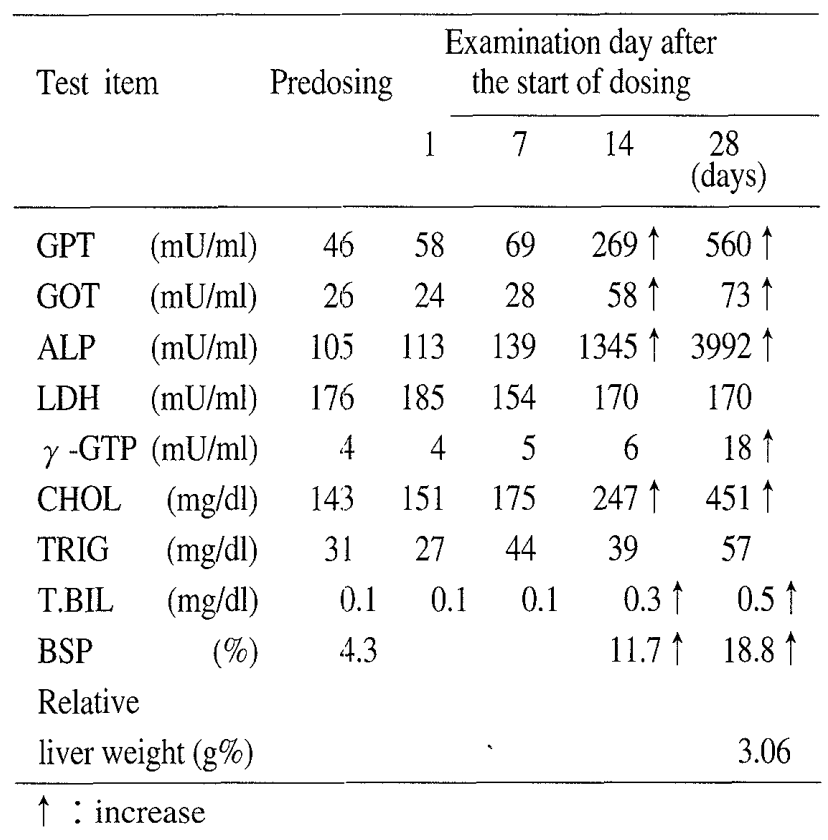


numerous microbodies (Photo. 11) were observed.

Increased liver weight and proliferation of microbodies were observed in rats given alkoxyacetophenone by admixture for 14 days, but there were no changes in blood biochemical parameters (Eacho et al., 1986). Increases in ALP and liver weight and proliferation of microbodies were observed in rats given gemcadiol by admixture for 90 days (Fitzgerald et al., 1986). In repeated dose toxicity studies of some hypolipidemic agents, liver weight and microbodies increased, but the grade depended on species (Lake et al., 1985; Lake et al., 1989), and microbodies did not increase in humans (Cohen, 1981). As others, there are many papers on the histopathology of microbodies including a detailed report on morphologic changes (Kondo et al., 1996).

Blood biochemical parameters in a male dog given compound C-1 p.o. for 28 days are shown in Table 9. Moderate increases in GPT, ALP, $\gamma$-GTP and T.BIL and increased BSP retention rate and very slight increases in GOT and CHOL were observed from day 14 after the start of dosing onward. Microscopically, green pigment deposits (Photo. 12) in the bile capillaries were observed, and electron microscopically, retention of amorphous material (Photo. 13) in

Table 10. Blood biochemical parameters in 1 female dog (No.12770) given compound E-3 p.o. for 90 days.

\begin{tabular}{|c|c|c|c|c|c|}
\hline \multirow{2}{*}{\multicolumn{2}{|c|}{ Test item }} & \multirow[t]{2}{*}{ Predosing } & \multicolumn{3}{|c|}{$\begin{array}{l}\text { Examination day after } \\
\text { the start of dosing }\end{array}$} \\
\hline & & & 35 & 63 & $\begin{array}{c}90 \\
\text { (days) }\end{array}$ \\
\hline GPT & $(\mathrm{mU} / \mathrm{ml})$ & 24 & 32 & 29 & 21 \\
\hline GOT & $(\mathrm{mU} / \mathrm{ml})$ & 35 & 39 & 29 & 35 \\
\hline ALP & $(\mathrm{mU} / \mathrm{ml})$ & 139 & $345 \uparrow$ & $366 \uparrow$ & $465 \uparrow$ \\
\hline $\mathrm{LDH}$ & $(\mathrm{mU} / \mathrm{ml})$ & 106 & 164 & 164 & $291 \uparrow$ \\
\hline$\gamma-\mathrm{GTP}$ & $(\mathrm{mU} / \mathrm{ml})$ & 2 & 3 & 2 & 2 \\
\hline CHOL & $(\mathrm{mg} / \mathrm{dl})$ & 121 & 230 & $396 \uparrow$ & $326 \uparrow$ \\
\hline TRIG & $(\mathrm{mg} / \mathrm{dl})$ & 20 & 21 & 75 & 44 \\
\hline T.BIL & $(\mathrm{mg} / \mathrm{dl})$ & 0.1 & 3.2 & 0.1 & 0.1 \\
\hline BSP & $(\%)$ & 2.5 & & 3.6 & 2.8 \\
\hline \multicolumn{6}{|c|}{ Relative } \\
\hline \multicolumn{3}{|c|}{ liver weight ( $\mathrm{g} \%$ ) } & & & $4.48 \uparrow$ \\
\hline
\end{tabular}

$\uparrow$ : increase moderately dilated bile capillaries was observed in the same site. The substance was identified as polymers of compound $\mathrm{C}-1$ by analysis of the liver extract.

There were scarcely any papers describing retention of dosing compounds using blood chemical parameters and morphologic changes. Since these changes are similar to the findings of cholestasis, we should take a cautious attitude for determination of retention substances in toxicity studies.

In accumulation-type hepatic injury, various kinds of blood biochemical parameters were affected by several conditions such as accumulated materials (intra- and extracellular materials) and sites (intra- and extracellular), and frequently there were no effects on any blood biochemical parameters. Therefore, we should regard increases in liver weight with sufficient care.

\section{Sinusoidal cells injury \\ Kupffer cells}

In a female dog given compound O-1 i.v. for 90 days, there were no abnormal changes in any blood biochemical parameters and scarcely any changes in histopathology except slight dilatation of the sinusoid. However, electron microscopically, vacuolar material containing a dense body was accumulated in the Kupffer cells (Photo. 14). The vacuoles gathered and formed small autolysosomes, and the residual

Table 11. Expected pharmacological effects of each compound.

\begin{tabular}{cl}
\hline Compound & Pharmacological effect \\
\hline A & Circulatory agents \\
B & CNS acting agents including anti- \\
& inflammatory analgesics \\
C & Gastrointestinal agents \\
D & Antiallergic agents including \\
& antirrheumatics \\
E & Metabolic agents including \\
& antidiabetics and agents for \\
& metabolic bone disease \\
M & Antibiotics and antifungal agents \\
$\mathrm{N}$ & Chemotherapeutic agents \\
$\mathrm{O}$ & Special agents including bases \\
\hline
\end{tabular}


bodies were seen in some Kupffer cells.

\section{Ito cells}

Blood biochemical parameters in a female dog given compound E-3 p.o. for 90 days are shown in Table 10. Slight increases in ALP, LDH and CHOL were observed continuously from 1 month after the start of dosing, and liver weight was increased markedly at necropsy. Microscopically, only dilatation of the sinusoid with swelling of the sinusoid cells (Photo. 15) was observed, but electron microscopically, an increase in swollen Ito cells (Photo. 16) containing large-sized fatty droplets and swollen
Kupffer cells which phagocytized hepatocytes with degenerated necrosis were observed.

Proliferation of the Kupffer cells and Pit cells was observed in rats given interleukin-2 i.v. for 7 days (Bouwens et al., 1990).

In the case of sinusoidal cell injury, it is difficult to confirm the injury from the blood biochemical parameters used routinely in recent toxicity studies. However, it is known that 4 cell types consisting of the sinusoid wall, i.e. the Kupffer cells, Ito cells, Pit cells and endothelial cells, play an important role in the onset of hepatocellular injury. Since dilatation of the sinusoid is observed occasionally in toxicity

Table 12. Blood biochemical parameters and relative liver weights in rats given vehicle for 14,28 or 90 days.

\begin{tabular}{|c|c|c|c|c|c|c|c|}
\hline \multirow{3}{*}{ Test item } & \multicolumn{7}{|c|}{ Examination day after the start of dosing } \\
\hline & \multirow[t]{2}{*}{ Unit } & \multicolumn{2}{|c|}{$\begin{array}{c}14 \\
(\mathrm{n}=250)\end{array}$} & \multicolumn{2}{|c|}{$\begin{array}{c}28 \\
(\mathrm{n}=120)\end{array}$} & \multicolumn{2}{|c|}{$\begin{array}{cc}90 & \text { (days) } \\
(\mathrm{n}=190) & \end{array}$} \\
\hline & & 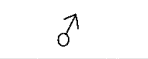 & 우 & $\delta$ & 우 & $0^{\pi}$ & 우 \\
\hline \multirow[t]{2}{*}{ GPT } & $(\mathrm{mU} / \mathrm{ml})$ & 40 & 32 & 39 & 32 & 36 & 37 \\
\hline & & $27-58$ & $23-45$ & $26-57$ & 23-45 & $21-61$ & $19-74$ \\
\hline \multirow[t]{2}{*}{ GOT } & $(\mathrm{mU} / \mathrm{ml})$ & 73 & 67 & 68 & 59 & 62 & 61 \\
\hline & & $52-101$ & $52-87$ & $50-92$ & $45-78$ & $41-94$ & $33-112$ \\
\hline \multirow[t]{2}{*}{ ALP } & $(\mathrm{mU} / \mathrm{ml})$ & 658 & 426 & 507 & 284 & 309 & 181 \\
\hline & & 459-945 & $279-652$ & $353-726$ & $189-426$ & $192-497$ & $94-349$ \\
\hline \multirow[t]{2}{*}{ LDH } & $(\mathrm{mU} / \mathrm{ml})$ & 249 & 198 & 247 & 228 & 229 & 173 \\
\hline & & $77-807$ & $55-714$ & $114-535$ & $65-796$ & $66-798$ & $58-513$ \\
\hline \multirow[t]{2}{*}{$\gamma$-GTP } & $(\mathrm{mU} / \mathrm{ml})$ & 1 & 1 & 1 & 1 & 1 & 1 \\
\hline & & $1-2$ & $1-2$ & $1-2$ & $1-2$ & $1-2$ & $1-2$ \\
\hline \multirow[t]{2}{*}{ CHOL } & $(\mathrm{mg} / \mathrm{dl})$ & 58 & 65 & 56 & 66 & 62 & 69 \\
\hline & & $44-72$ & $47-83$ & $45-68$ & $50-82$ & 43-80 & $46-91$ \\
\hline \multirow[t]{2}{*}{ TRIG } & $(\mathrm{mg} / \mathrm{dl})$ & 135 & 57 & 150 & 69 & 157 & 87 \\
\hline & & $64-283$ & $21-158$ & $82-276$ & $23-207$ & $75-327$ & $28-263$ \\
\hline \multirow[t]{2}{*}{ T.BIL } & $(\mathrm{mg} / \mathrm{dl})$ & 0.1 & 0.1 & 0.1 & 0.1 & 0.1 & 0.1 \\
\hline & & $0.1-0.2$ & $0.1-0.2$ & $0.1-0.2$ & $0.1-0.2$ & $0.1-0.2$ & $0.1-0.2$ \\
\hline \multicolumn{8}{|l|}{ Relative } \\
\hline \multirow[t]{2}{*}{ liver weight } & $(\mathrm{g} \%)$ & 4.42 & 4.08 & 3.97 & 3.76 & 3.50 & 3.23 \\
\hline & & $3.87-4.98$ & $3.50-4.65$ & $3.51-4.42$ & $3.24-4.27$ & $3.01-4.00$ & $2.82-3.64$ \\
\hline
\end{tabular}

Values: Mean $\pm 2 \mathrm{SD}$

The animals for 14-, 28- and 90-day repeated dose toxicity studies were analyzed at the age of 8,10 and 19 weeks, respectively. GPT: Glutamic pyruvic transaminase

ALP: Alkaline phosphatase GOT: Glutamic oxaloacetic transaminase

$\gamma$-GTP: Gamma-glutamyl transpeptidase LDH: Lactate dehydrogenase

TRIG: Triglyceride

CHOL: Total cholesterol

T.BIL: Total bilirubin 
studies and electron microscopy is useful, this item was added to the present report.

\section{Others}

Adaptive responses (proliferation of smooth endoplasmic reticulum)

In a male rat given compound B-2 i.p. for 14 days, a slight increase in ALP (936 mU/ml) and increased relative liver weight $(5.44 \mathrm{~g} \%)$ were observed, and slight increases in ALP (215 $\mathrm{mU} / \mathrm{ml})$ and CHOL $(311 \mathrm{mg} / \mathrm{dl})$ and increased liver weight $(3.65 \mathrm{~g} \%)$ in a female dog given compound B-3 p.o. for 90 days. Microscopically, enlargement and paleness of the hepato- cytes (Photo. 17b) were observed in all cases, and electron microscopically distinct diffused proliferation (Photo. 18) and focal whorled proliferation of the smooth endoplasmic reticulum were observed.

Electron microscopically, a marked increase in the smooth endoplasmic reticulum was observed in rats given phenobarbital i.p. for 5 days (Stäubli et al., 1969) and increased smooth endoplasmic reticulum with decreased glycogen and increased fatty droplets (Feldman et al., 1980) in rats given the drug p.o. for 7 days. Additionally, there are many papers which cite similar changes as follows: slight decrease in

Table 13. Blood biochemical parameters and relative liver weights in dogs given vehicle for 14,28 or 90 days.

\begin{tabular}{|c|c|c|c|c|c|c|c|}
\hline & & Exan & day after th & of dosing & & & \\
\hline Test item & Unit & & & & & & (days) \\
\hline & & $(n=235)$ & $(n=205)$ & $(\mathrm{n}=195)$ & $(n=210)$ & $(\mathrm{n}=100)$ & $(n=95)$ \\
\hline & & $\pi$ & 우 & $\pi$ & 우 & त & 우 \\
\hline GPT & $(\mathrm{mU} / \mathrm{ml})$ & 34 & 34 & 35 & 34 & 40 & 33 \\
\hline & & $21-54$ & $22-52$ & $21-59$ & $22-53$ & $19-86$ & $20-55$ \\
\hline GOT & $(\mathrm{mU} / \mathrm{ml})$ & 28 & 29 & 29 & 29 & 29 & 28 \\
\hline & & $20-40$ & $21-41$ & $21-40$ & $20-43$ & $20-43$ & $19-41$ \\
\hline ALP & $(\mathrm{mU} / \mathrm{ml})$ & 204 & 194 & 173 & 160 & 125 & 110 \\
\hline & & $130-321$ & $116-324$ & $97-307$ & $97-265$ & $66-239$ & $55-221$ \\
\hline $\mathrm{LDH}$ & $(\mathrm{mU} / \mathrm{ml})$ & 112 & 103 & 123 & 112 & 115 & 120 \\
\hline & & $47-269$ & $46-233$ & $48-316$ & $47-268$ & $45-291$ & $50-289$ \\
\hline$\gamma-\mathrm{GTP}$ & $(\mathrm{mU} / \mathrm{ml})$ & 2 & 2 & 2 & 2 & 3 & 3 \\
\hline & & $0-4$ & $0-4$ & $0-4$ & $0-4$ & $1-5$ & $1-5$ \\
\hline CHOL & $(\mathrm{mg} / \mathrm{dl})$ & 159 & 152 & 153 & 153 & 146 & 166 \\
\hline & & $105-212$ & $102-203$ & $105-200$ & $99-207$ & $93-200$ & $78-254$ \\
\hline TRIG & $(\mathrm{mg} / \mathrm{dl})$ & 44 & 51 & 39 & 46 & 35 & 51 \\
\hline & & $18-108$ & $21-120$ & $15-100$ & $18-117$ & $14-91$ & $20-129$ \\
\hline T.BIL & $(\mathrm{mg} / \mathrm{dl})$ & 0.1 & 0.1 & 0.1 & 0.1 & 0.1 & 0.1 \\
\hline & & $0.1-0.2$ & $0.1-0.2$ & $0.1-0.2$ & $0.1-0.2$ & $0.1-0.2$ & $0.1-0.2$ \\
\hline Relative & & Age: 7 & onths & $\partial^{\lambda} \mathrm{n}=89$ & & $-3.03)$ & \\
\hline liver weig & $(\mathrm{g} \%)$ & & & 우 $\mathrm{n}=85$ & & $-3.13)$ & \\
\hline
\end{tabular}

Values: Mean $\pm 2 \mathrm{SD}$

The animals for 14-, 28- and 90-day repeated dose toxicity studies were analyzed at the age of 6.5-7, 7.5-8 and 9.5-10 months, respectively.

GPT: Glutamic pyruvic transaminase

ALP: Alkaline phosphatase

$\gamma$-GTP: Gamma-glutamyl transpeptidase

TRIG: Triglyceride
GOT: Glutamic oxaloacetic transaminase

LDH: Lactate dehydrogenase

CHOL: Total cholesterol

T.BIL: Total bilirubin 


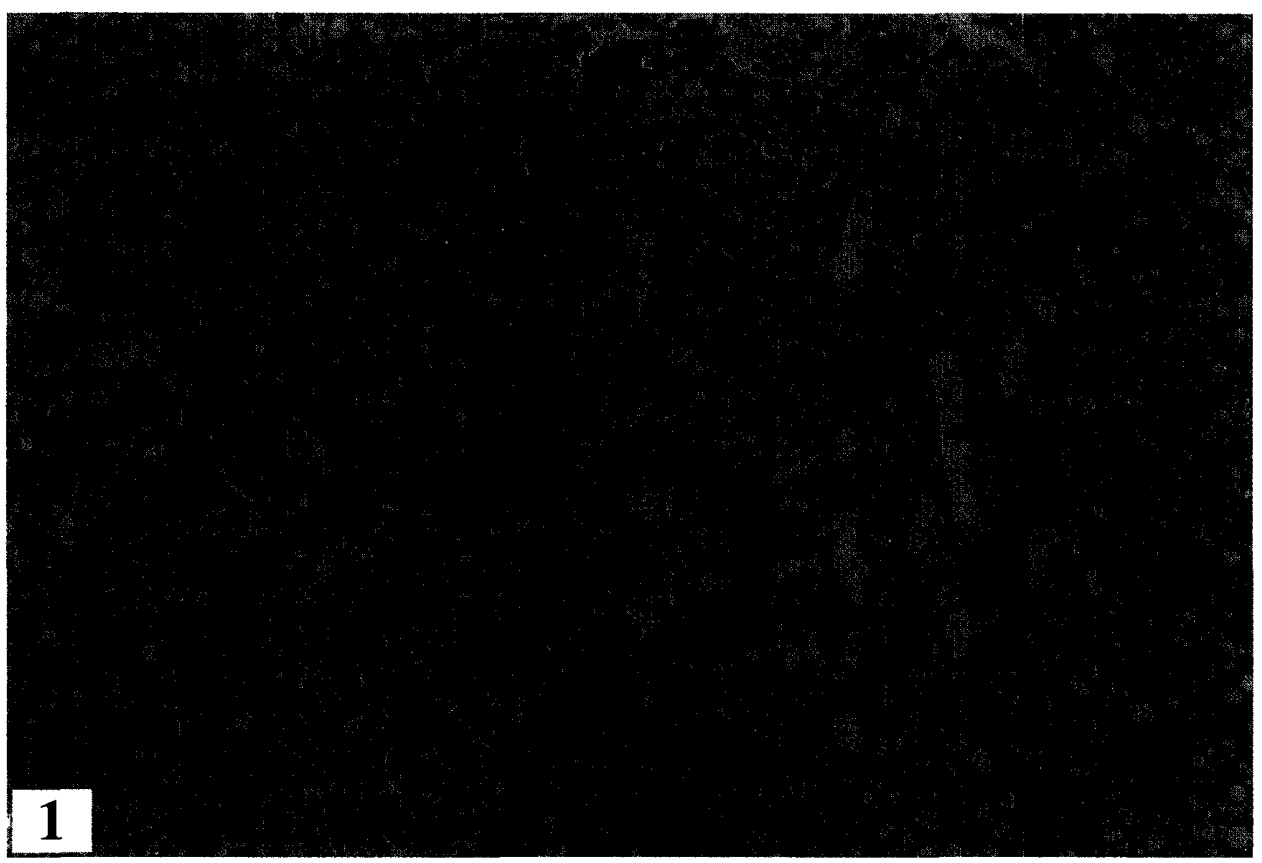

Photo 1. Liver from a rat treated with compound A-1 for 14 days.

Note: Necrosis with hemorrhage and vacuolation around the area. HE stain, $\times 200$.

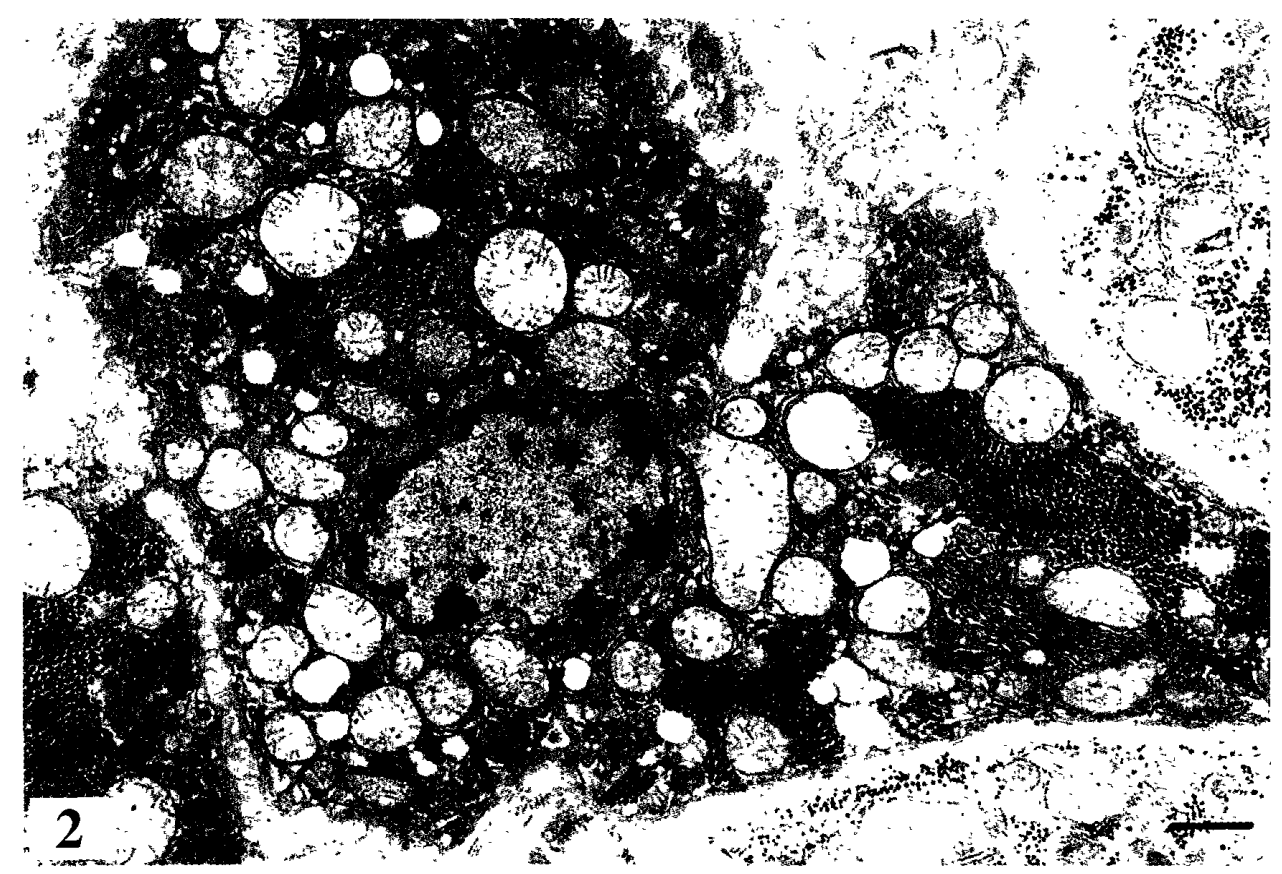

Photo 2. Liver from a dog treated with compound M-2 for 28 days.

Note: Deformity of the nucleus, increased density of the cytoplasm and swelling of the mitochondria. $\times 6,300$. 


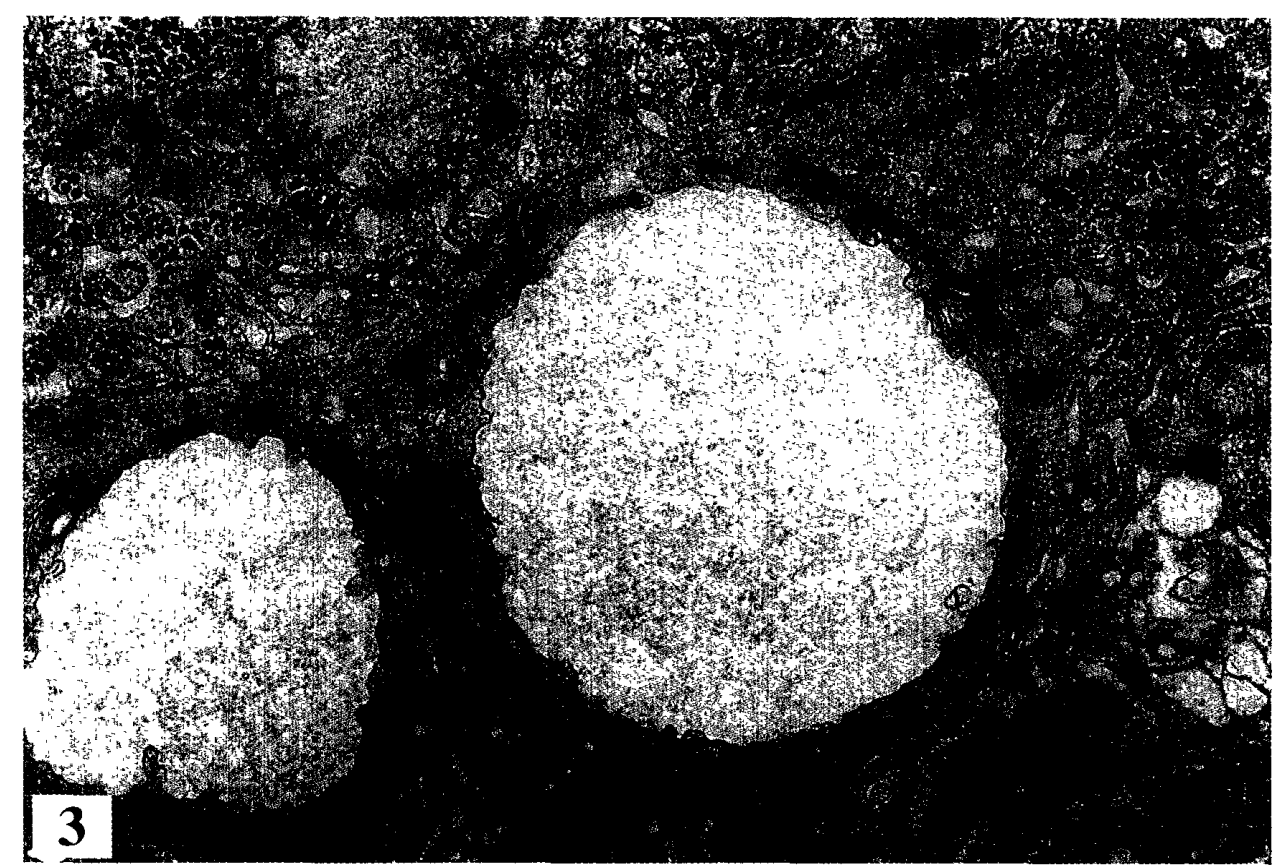

Photo 3. Liver from a dog treated with compound A-2 for 14 days.

Note: Degeneration of the cristae in the mitochondria, slight dilatation of the bile capillary and shortening or disappearance of the microvilli and cholestasis. $\times 14,000$.

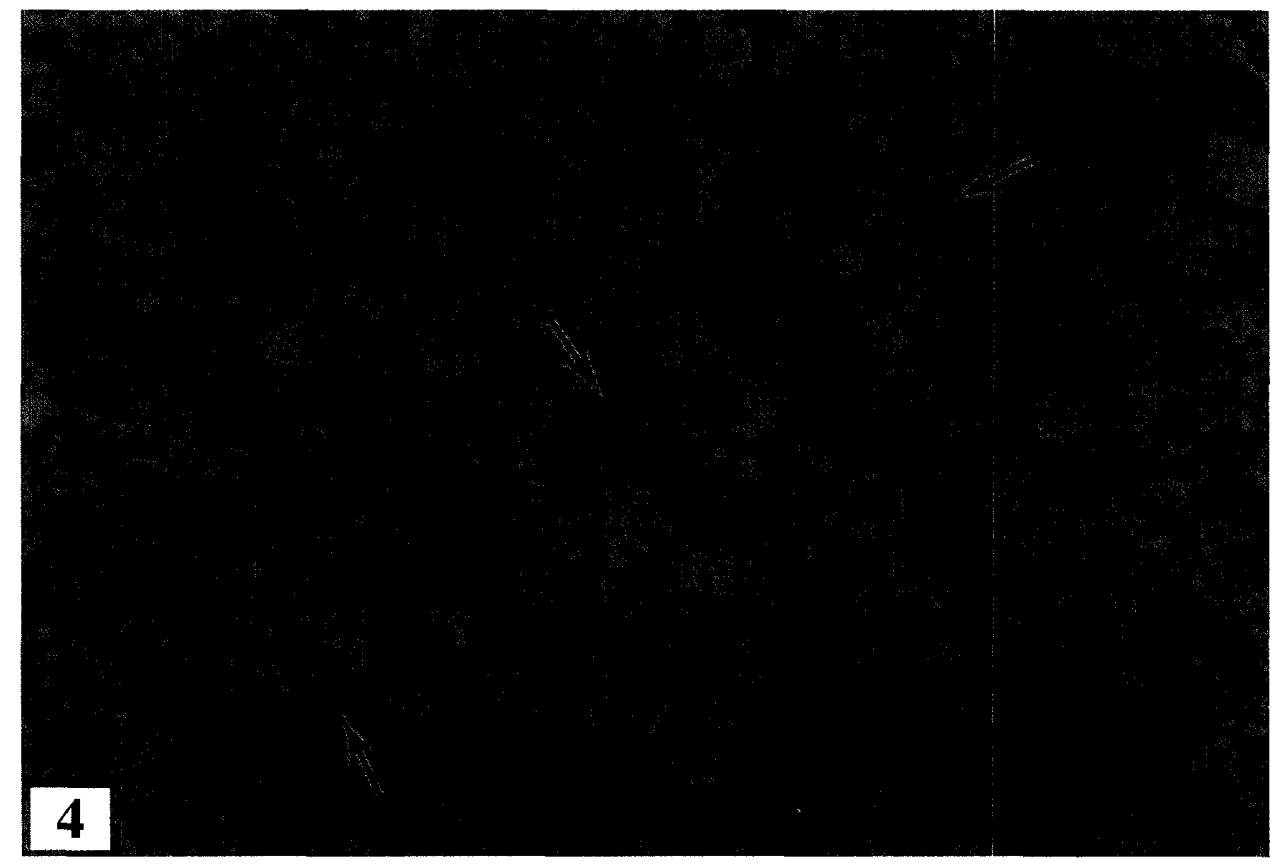

Photo 4. Liver from a dog treated with compound D-1 for 90 days.

Note: yellowish brown bile plugs in the bile capillary (arrow). HE stain, $\times 400$. 


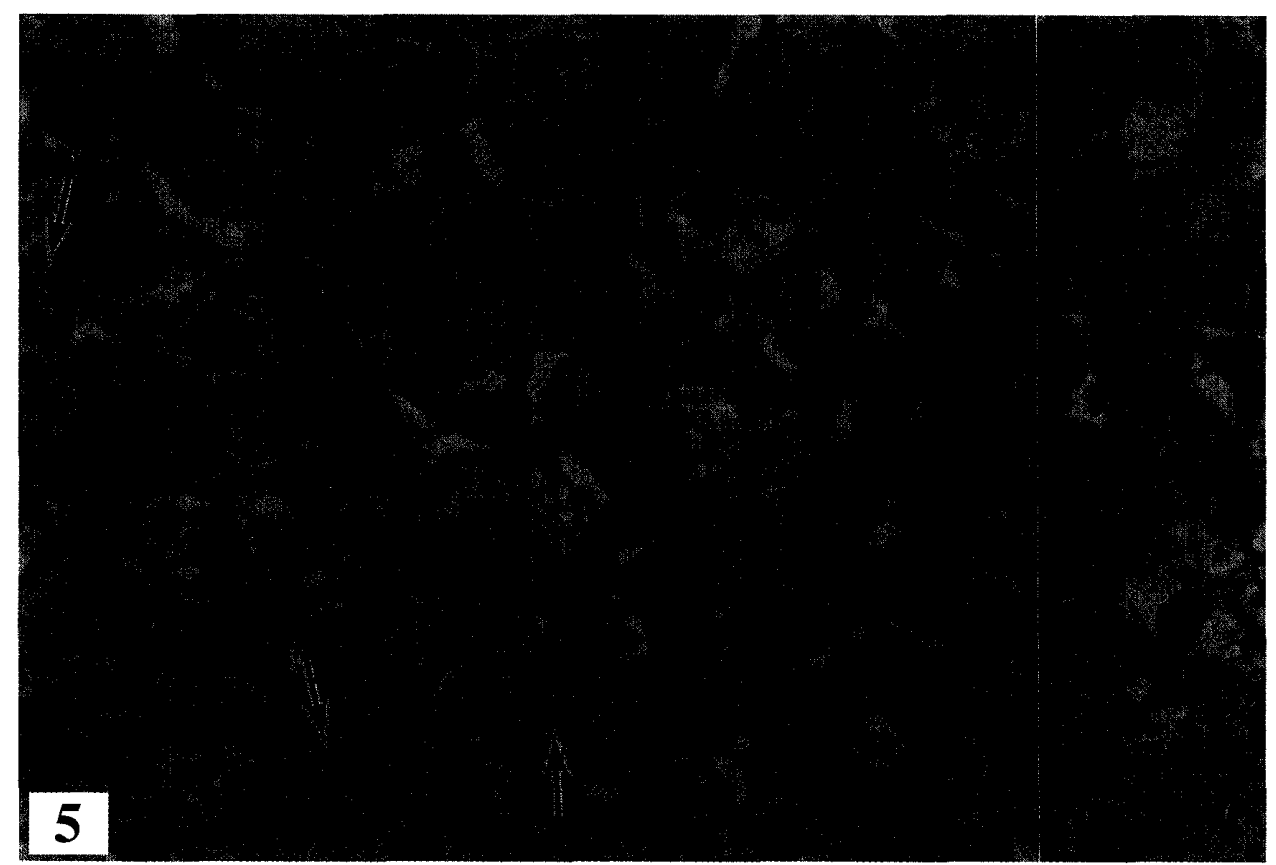

Photo 5. Liver from a dog treated with compound A-3 for 14 days.

Note: Inflammatory cell infiltration and dilatation of the bile duct (arrow). HE stain, $\times 400$.

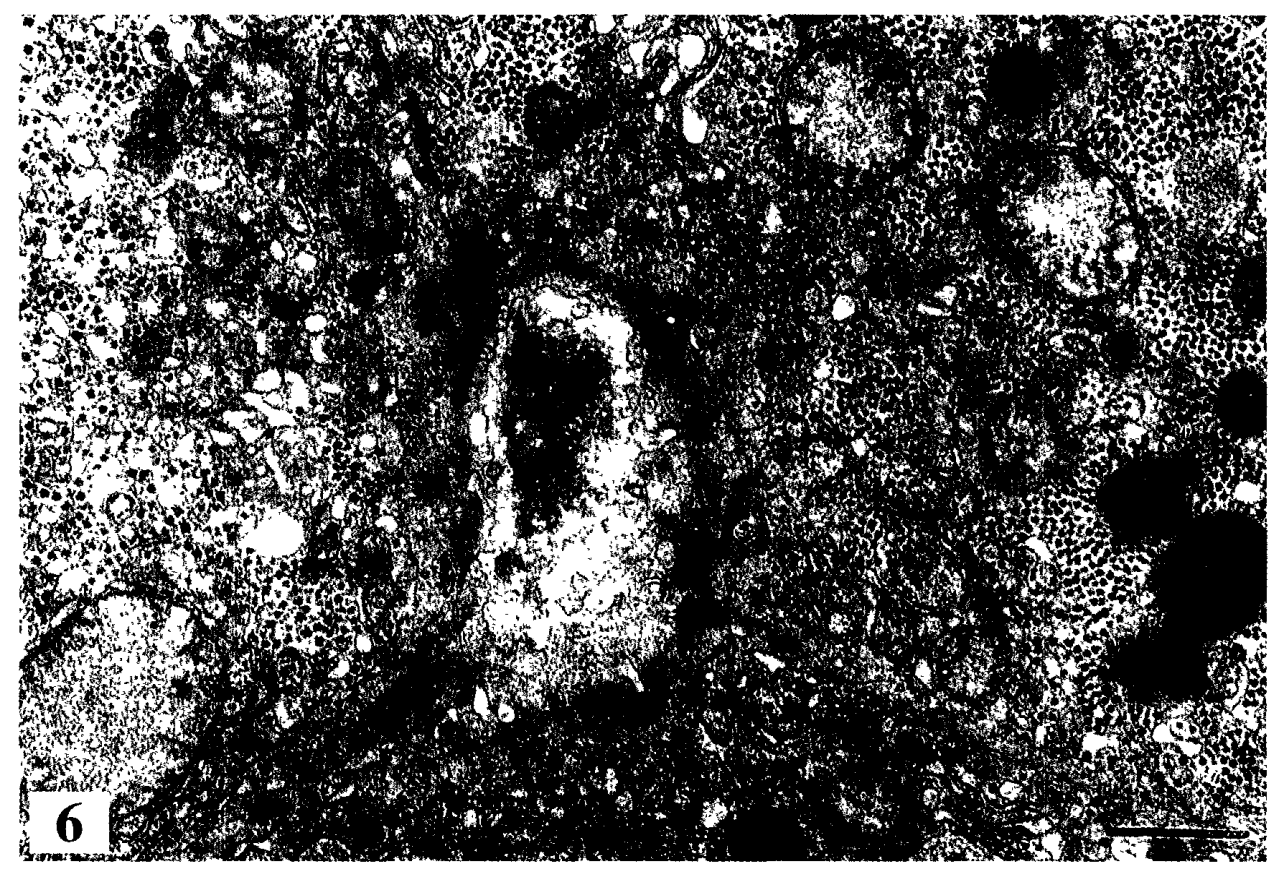

Photo 6. Liver from a dog treated with compound D-3 for 90 days.

Note: Bile pigment deposits in the hepatocytes and slight dilatation of the bile capillary. $\times 11,000$. 

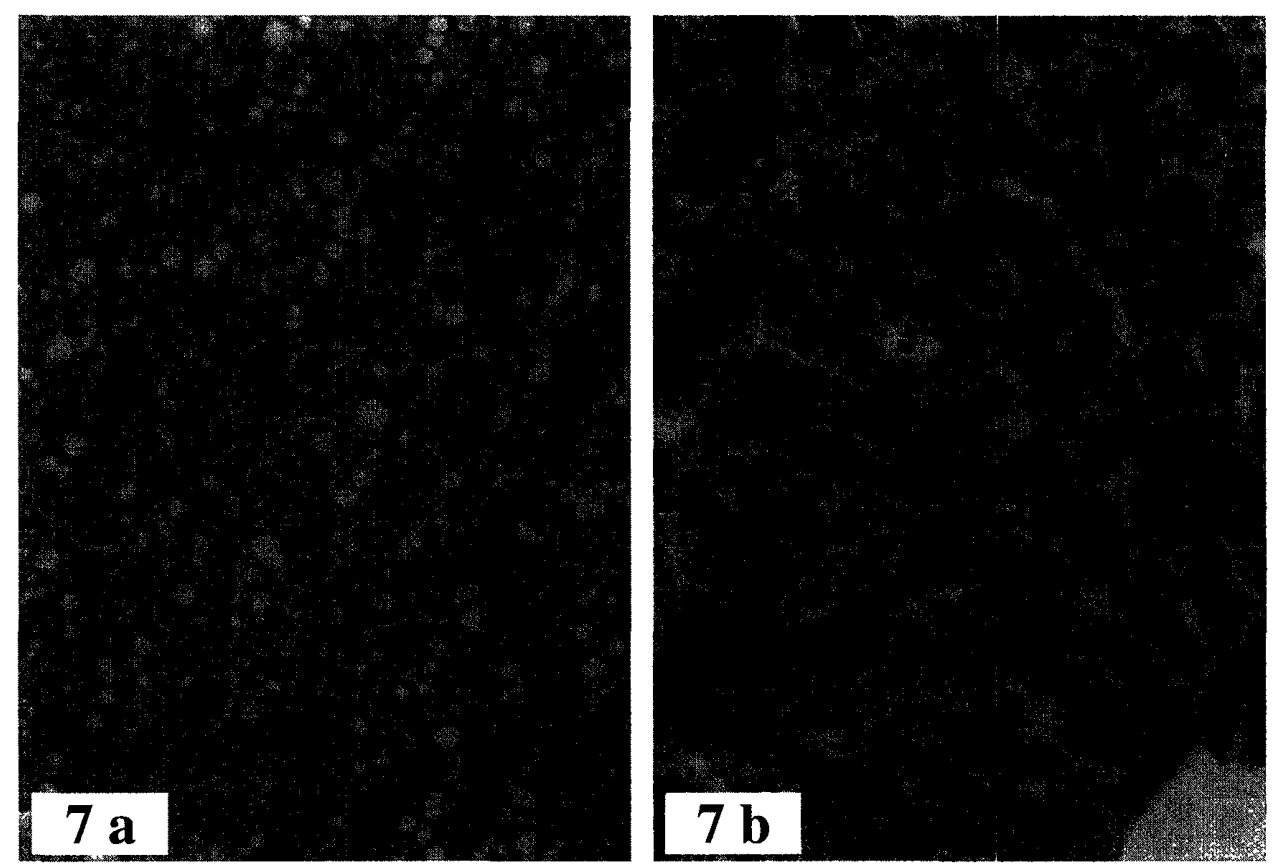

Photo 7a and 7b. Liver from a rat treated with compound B-1 for 4 days.

Note: Small or large vacuoles in the hepatocytes (7a) and numerous fatty droplets (7b). HE stain (7a), x400, oil red O stain (7b), $\times 200$.

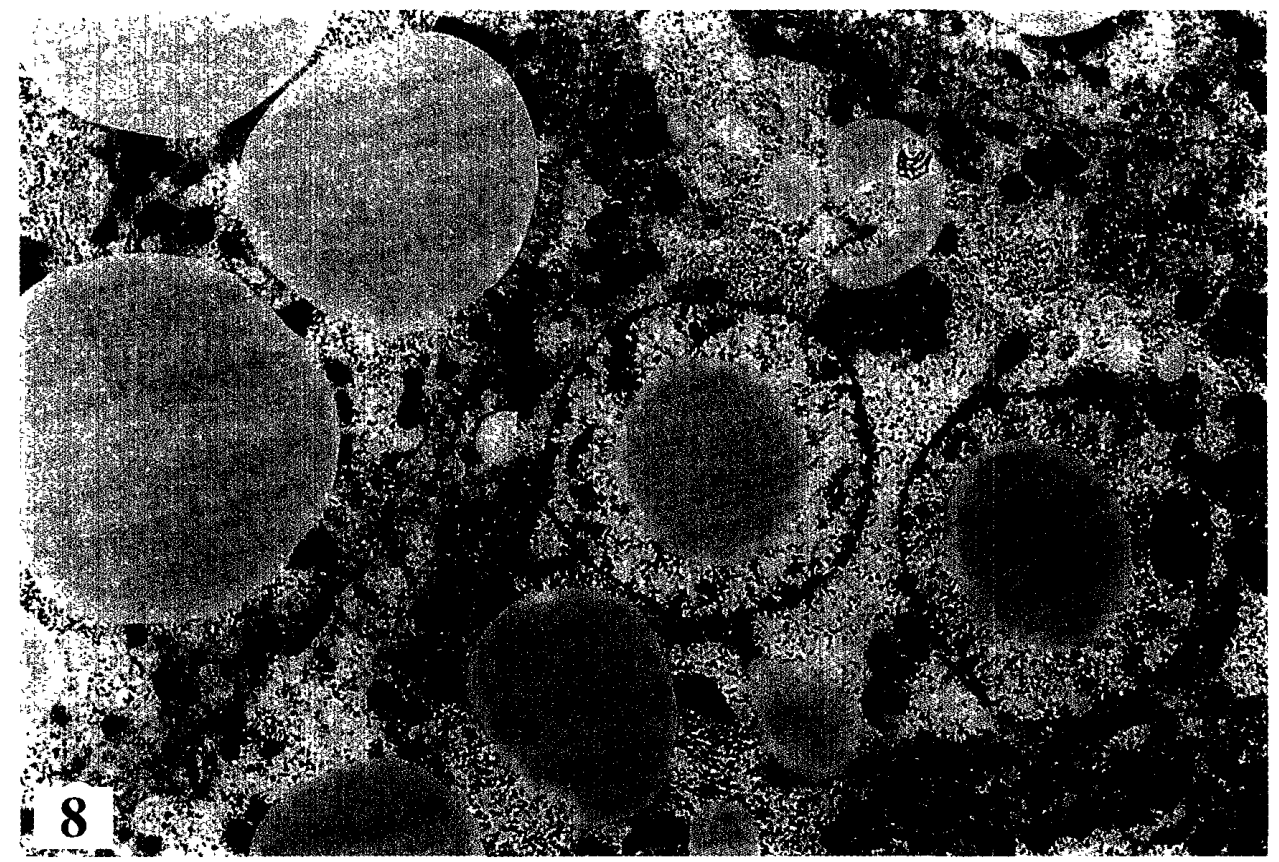

Photo 8. Liver from a rat treated with compound B-1 for 4 days.

Note: Fatty droplets in the nucleus and cytoplasm. $\times 3,000$. 


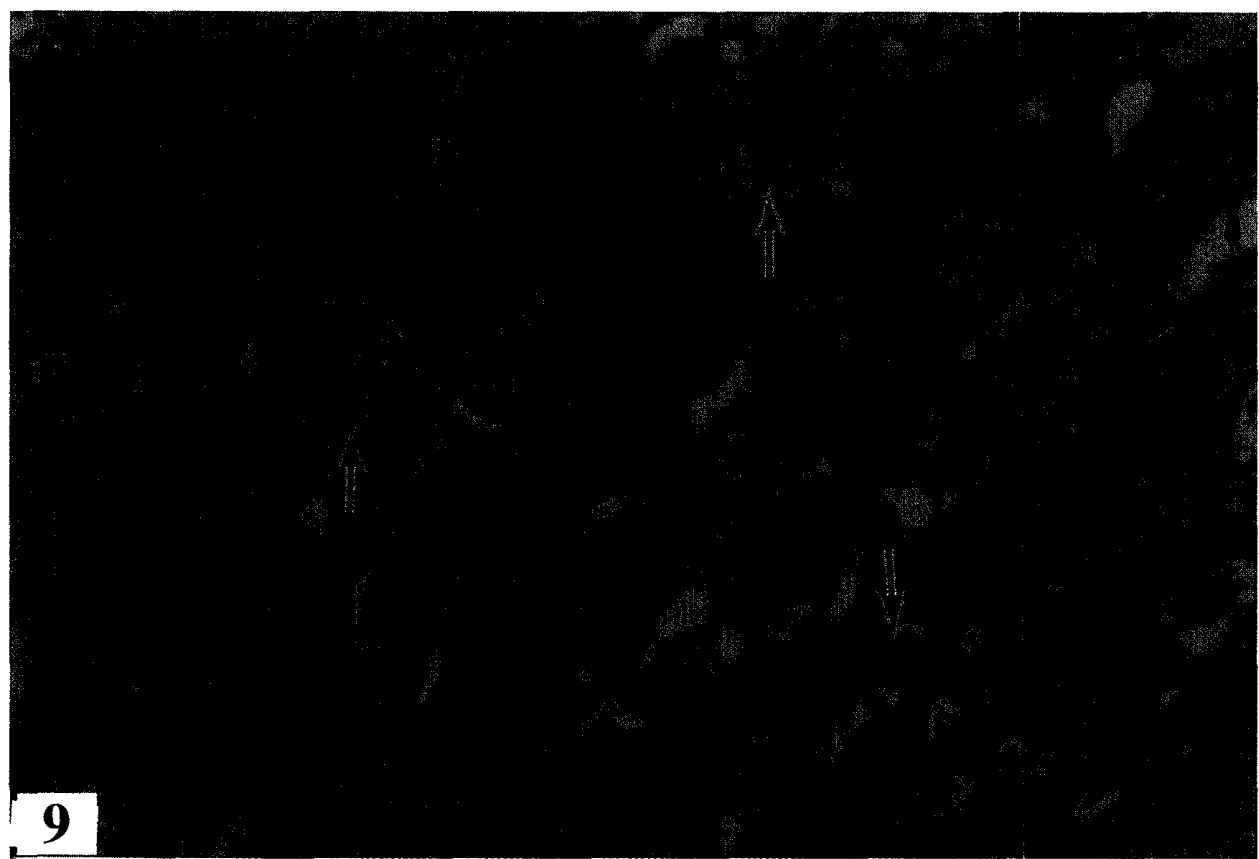

Photo 9. Liver from a rat treated with compound M-3 for 14 days.

Note: Eosinophilic material in the hepatocytes (arrow). HE stain, $\times 400$.

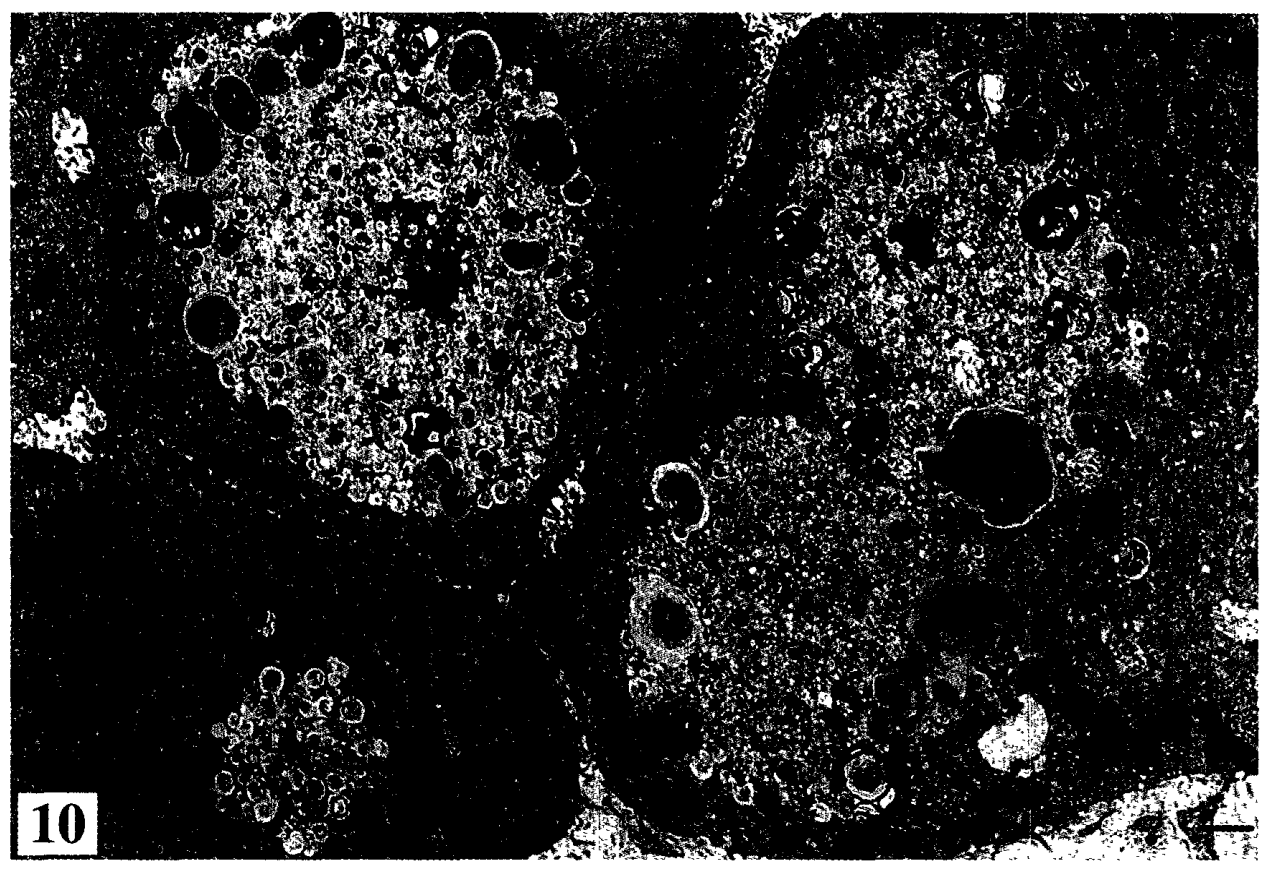

Photo 10. Liver from a rat treated with compound M-3 for 14 days.

Note: Numerous small myelin-like structures in autolysosomes in the hepatocytes. $\times 3,300$. 


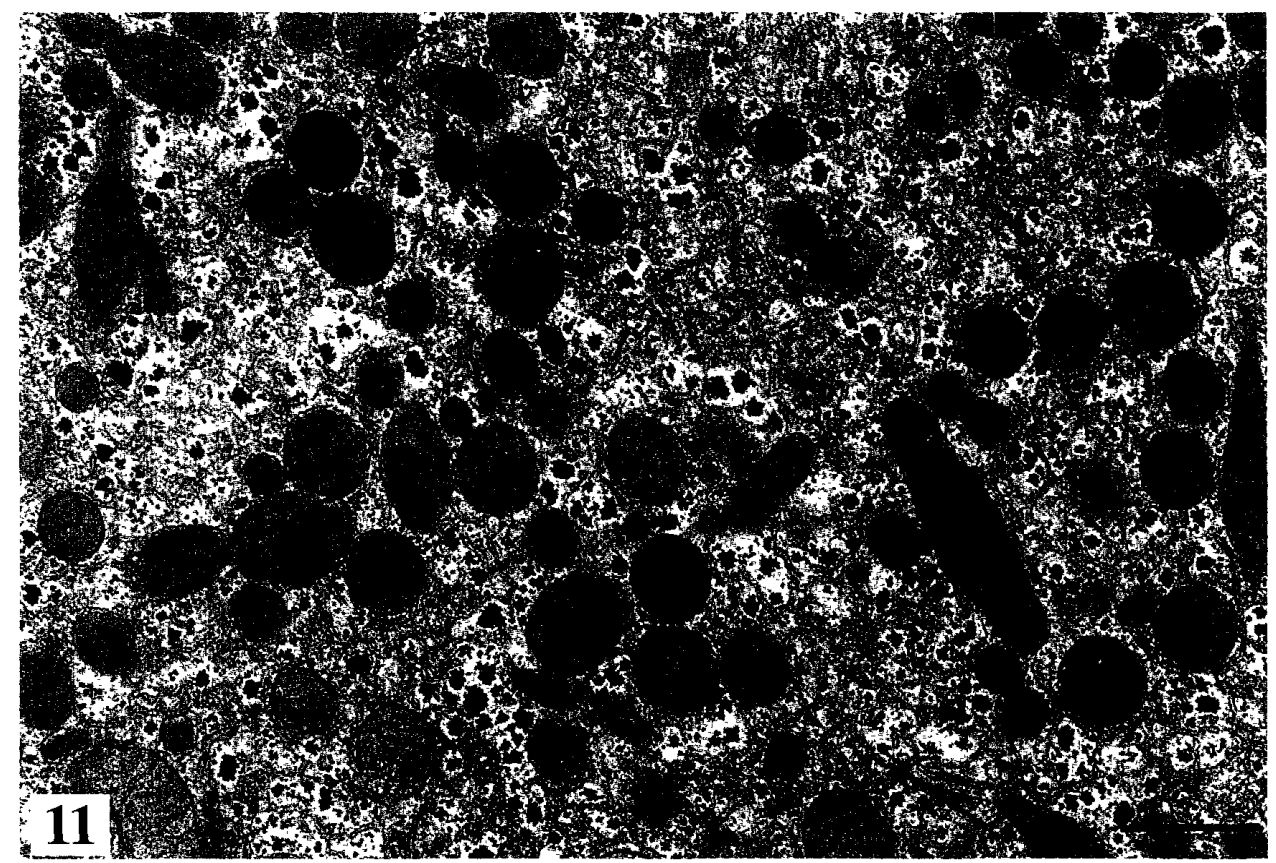

Photo 11. Liver from a rat treated with compound E-2 for 28 days.

Note: Slight deformity of the mitochondria and proliferation of the microbodies. $\times 1,100$.

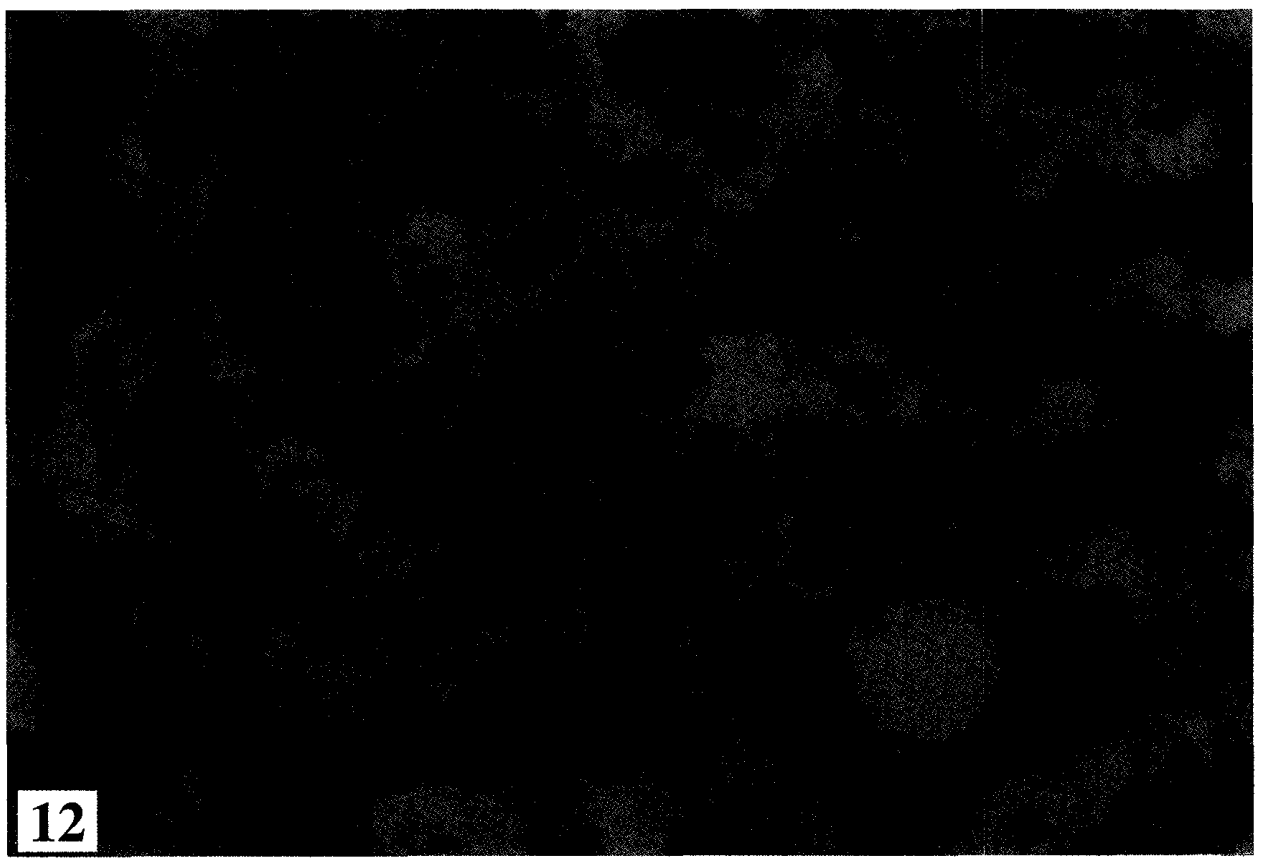

Photo 12. Liver from a dog treated with compound C-1 for 28 days.

Note: Green pigment deposition in the bile capillary. Kernechtrot stain, $\times 400$. 


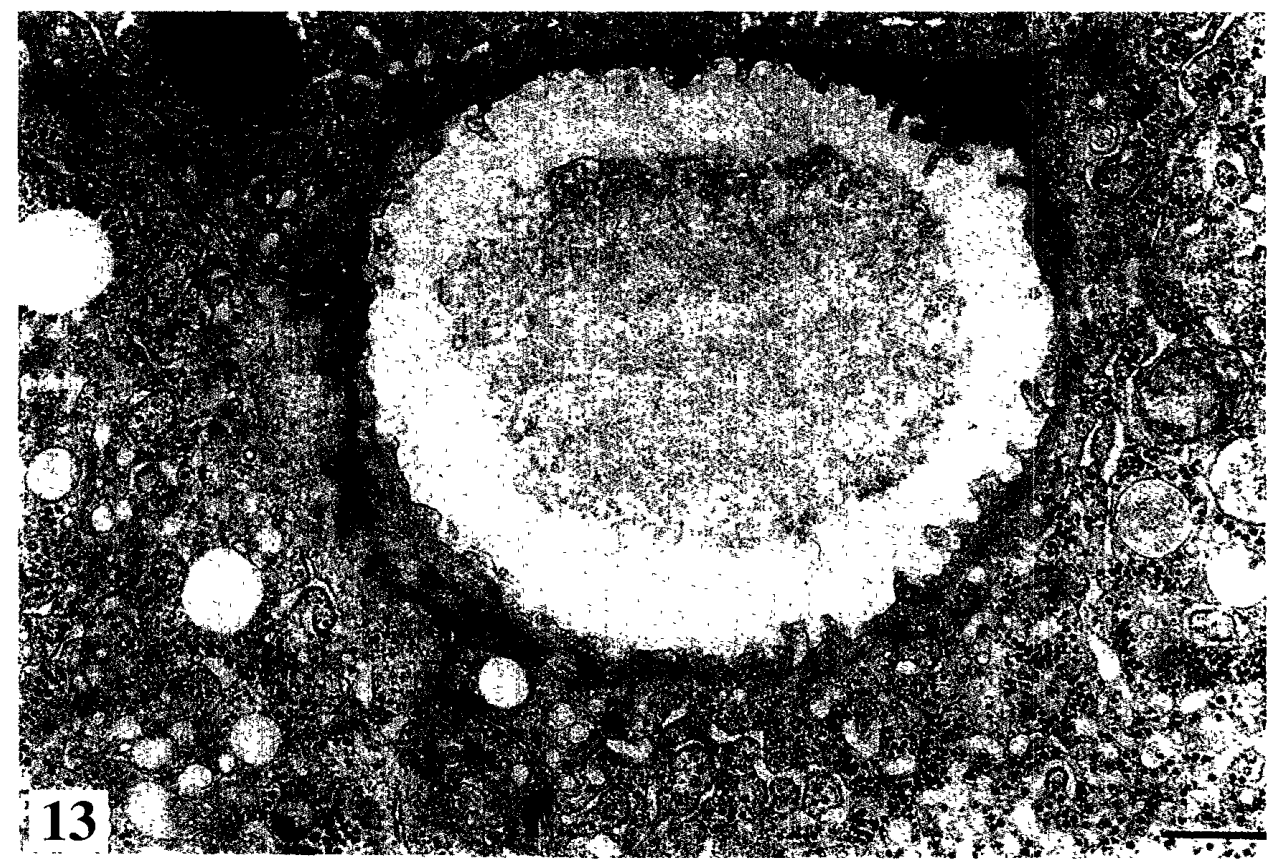

Photo 13. Liver from a dog treated with compound C-1 for 28 days.

Note: Retention of amorphous material in moderately dilated bile capillary. $\times 8,000$.

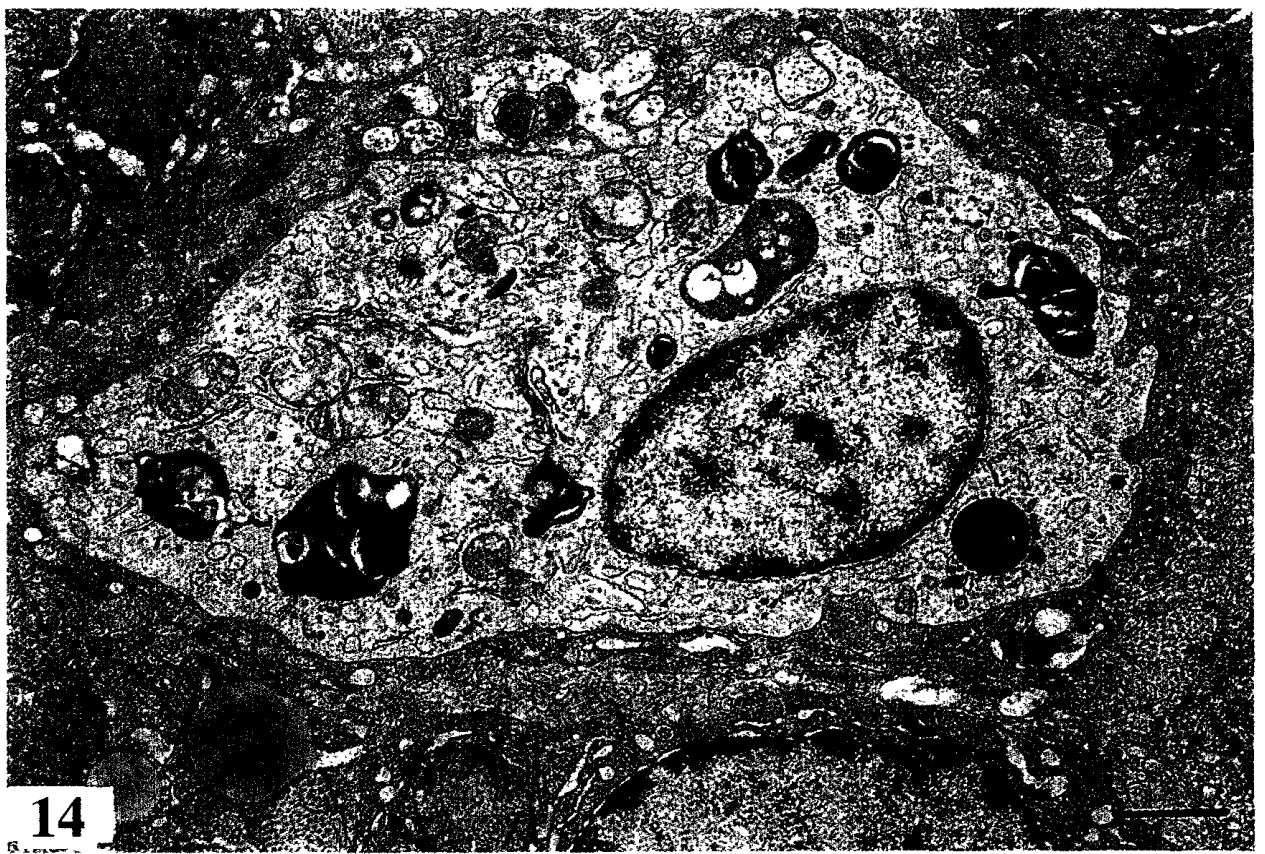

Photo 14. Liver from a dog treated with compound O-1 for 90 days.

Note: Vacuolar material containing dense body in the Kupffer cells. $\times 8,900$ 


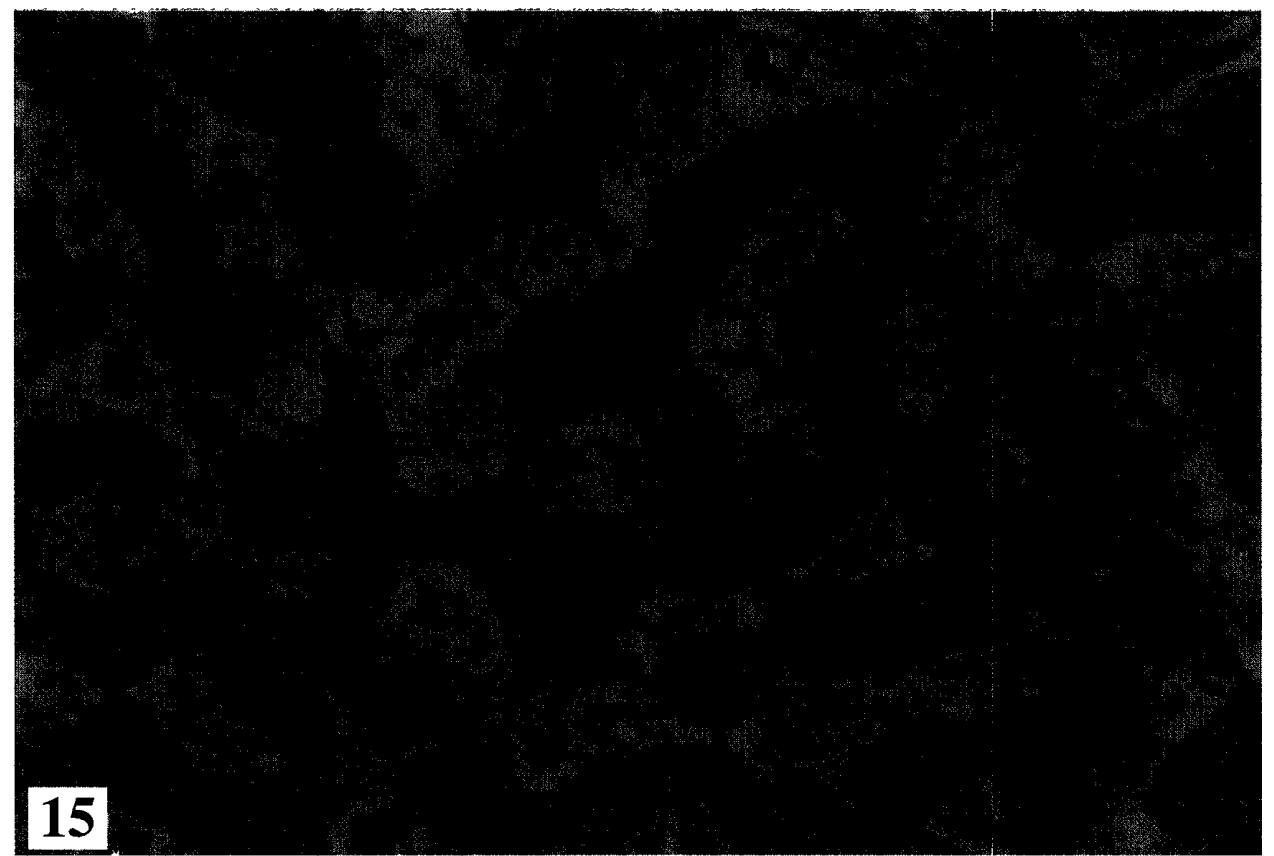

Photo 15. Liver from a dog treated with compound E-3 for 90 days.

Note: Dilatation of the sinusoid with swelling of the sinusoid cells. HE stain $\times 400$.

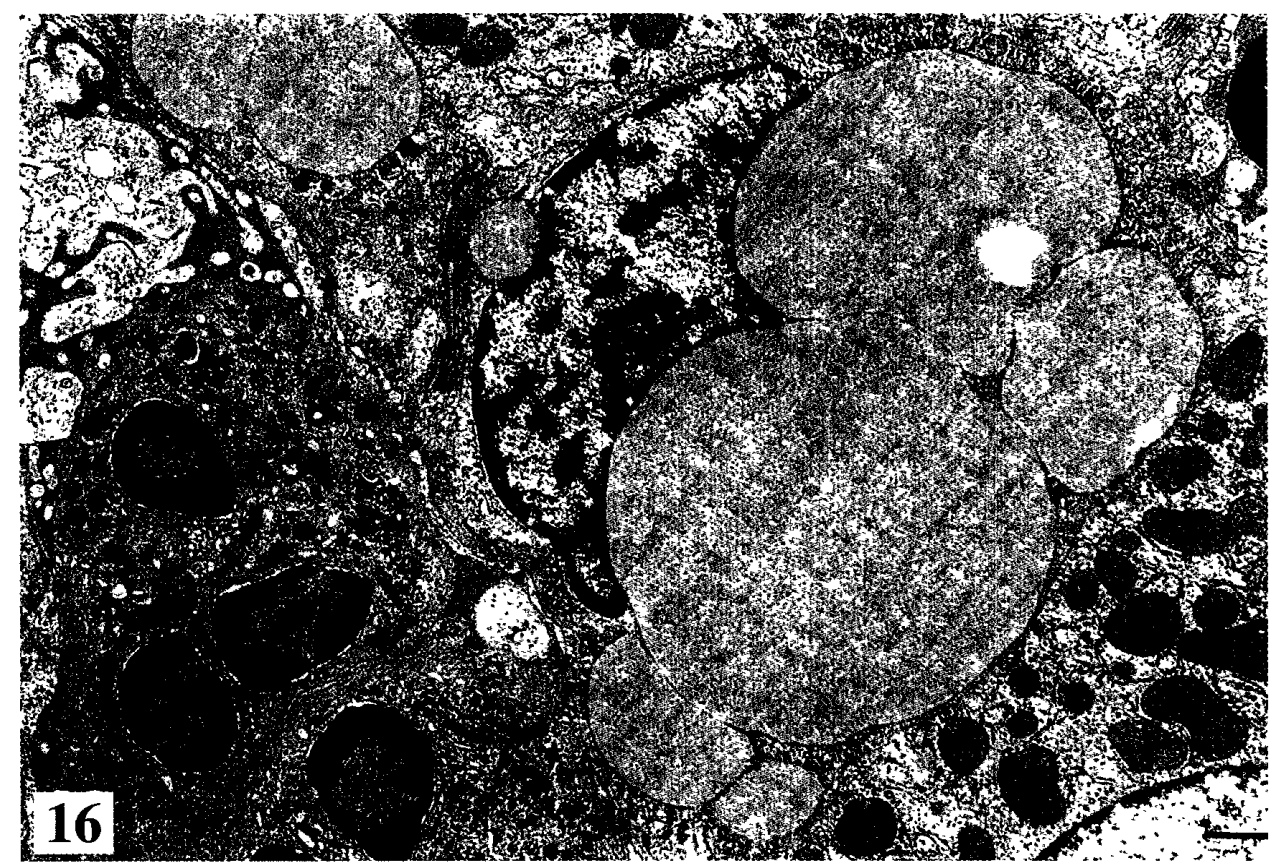

Photo 16. Liver from a dog treated with compound E-3 for 90 days.

Note: Increase in swelled Ito cells containing large sized fatty droplets. $\times 5,800$. 


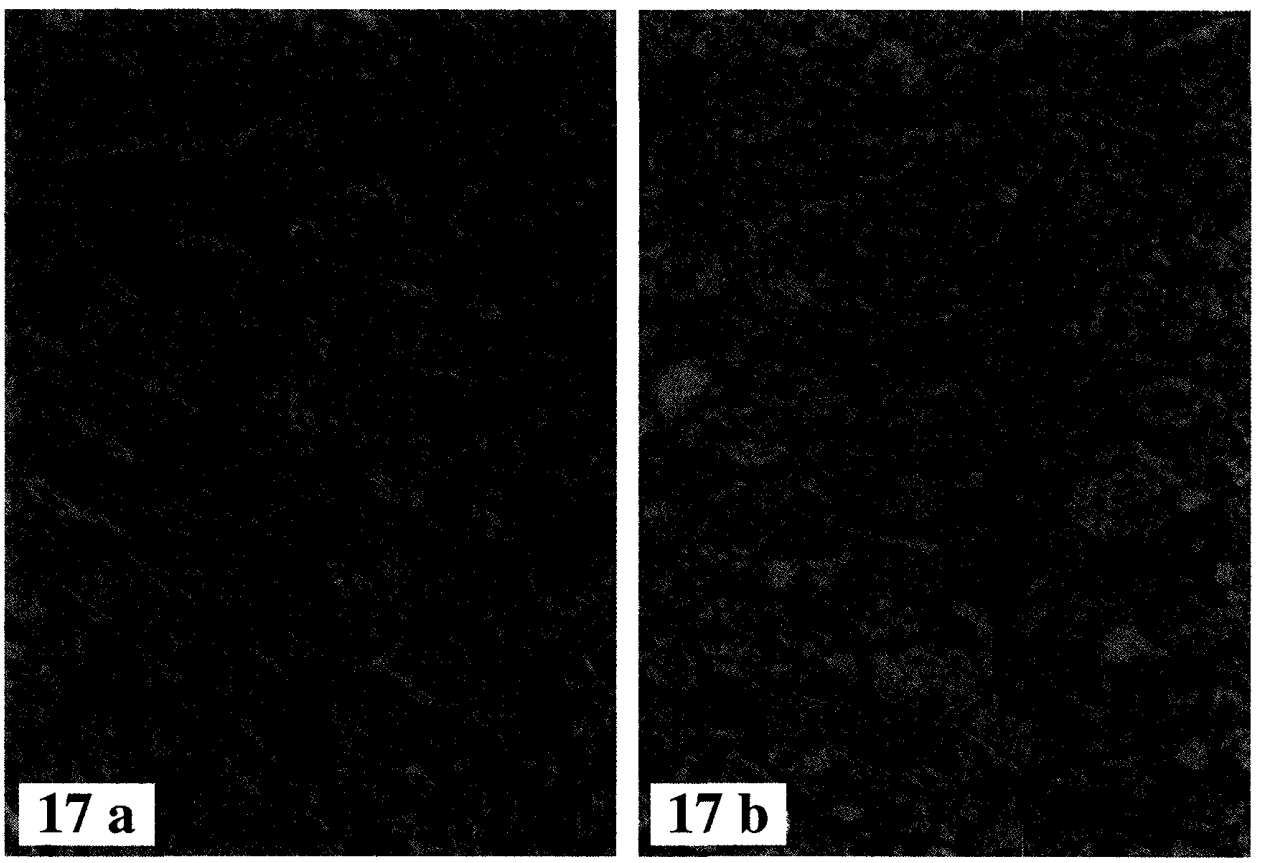

Photo 17a and 17b. Liver from a dog treated with compound B-3 for 90 days. Note: Enlargement and paleness of the hepatocytes $(17 \mathrm{~b})$ and normal hepatocytes $(17 \mathrm{a})$. HE stain, $\times 200$.

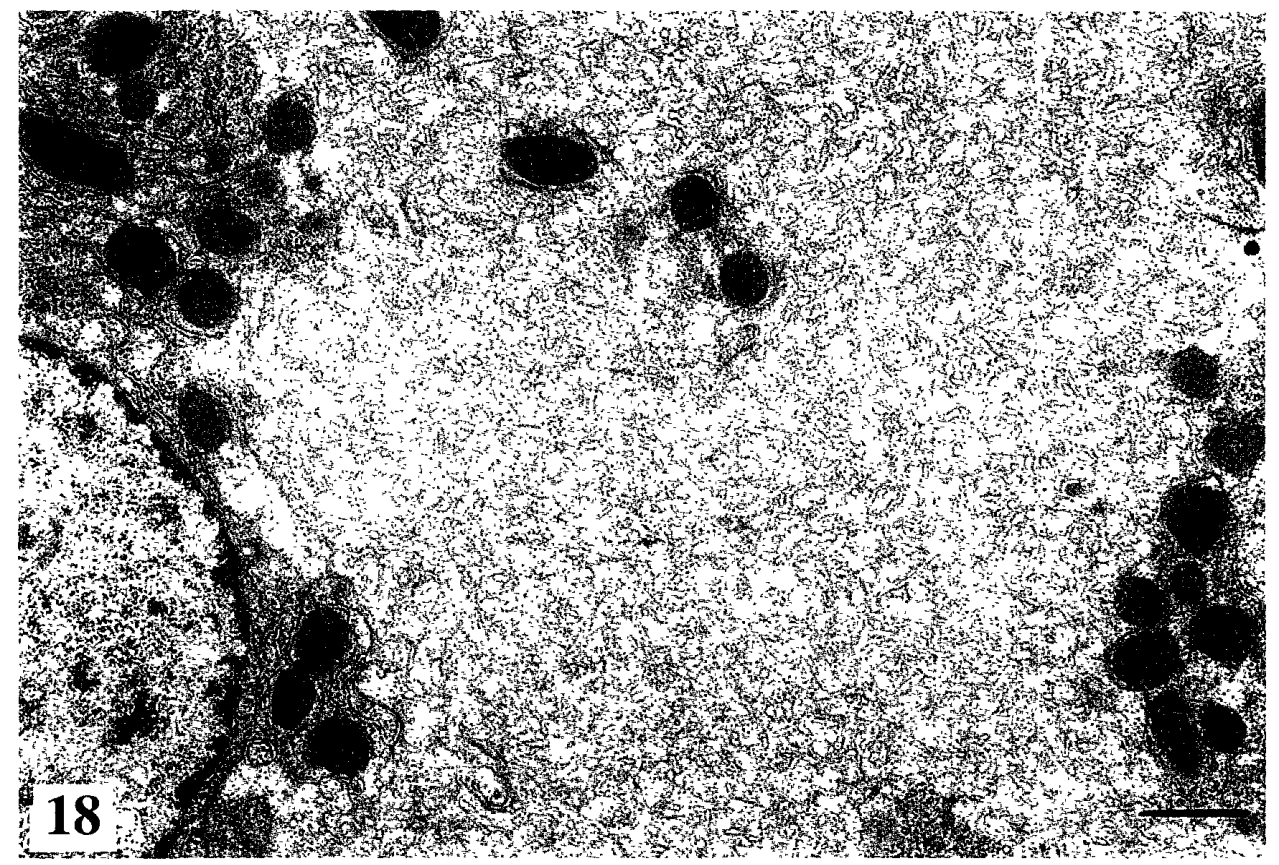

Photo 18. Liver from a dog treated with compound B-3 for 90 days.

Note: Diffused proliferation of the smooth endoplasmic reticulum. $\times 8,800$. 


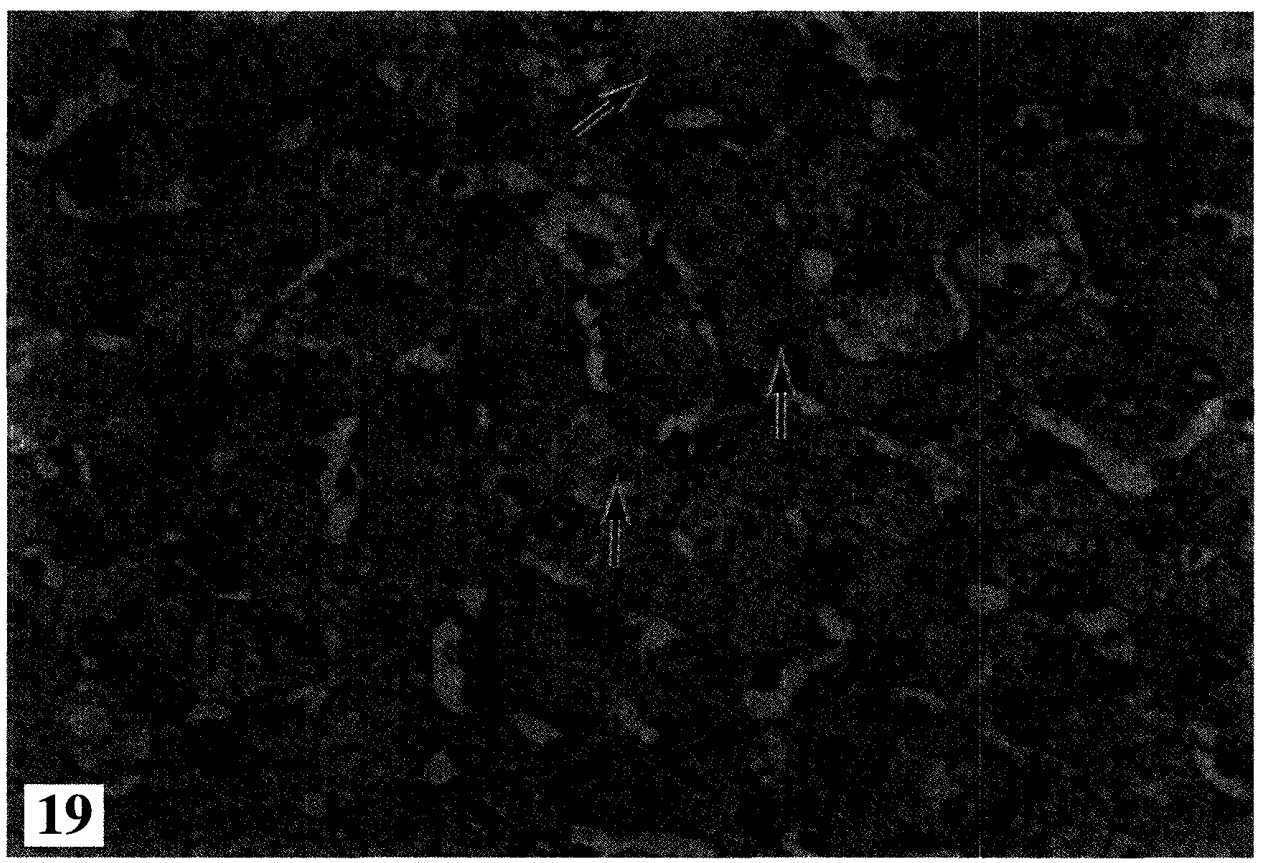

Photo 19. Liver from a dog treated with compound M-4 for 28 days. Note: Round eosinophilic body in the hepatocytes (arrow). HE stain, $\times 400$.

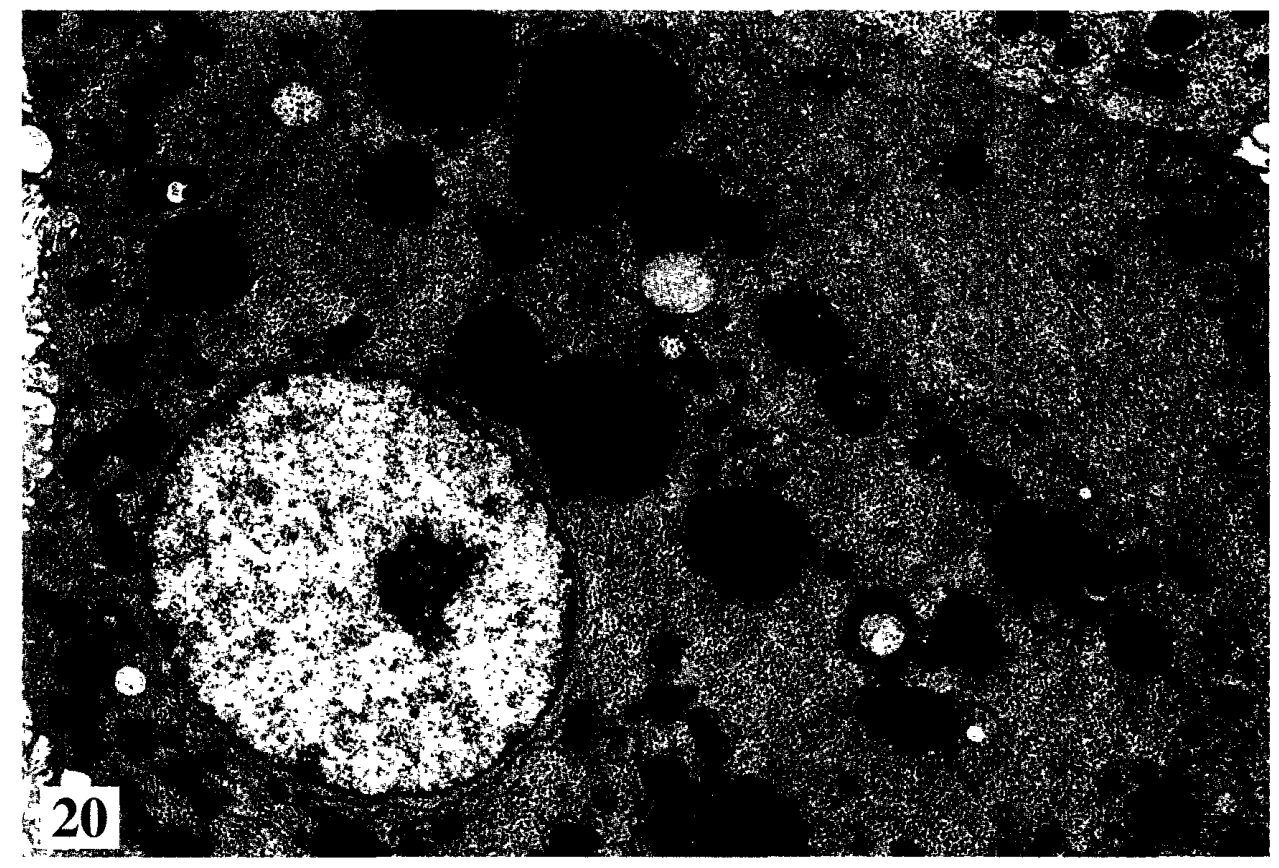

Photo 20. Liver from a dog treated with compound M-4 for 28 days.

Note: Several giant mitochondria in the hepatocytes. $\times 4,400$. 
ALP, increases in GPT, CHOL and liver weight and enlarged hepatocytes microscopically in rats given KB-944 p.o. for 30 days (Hirakawa et al.; 1982); slight changes of GPT, ALP and T.BIL without dose-dependency; increased liver weight and enlarged hepatocytes microscopically in rats given LY17883 p.o. for 14 days (Eacho et al., 1985); no changes in ALP, GOT, GPT or TRIG, slight increases in CHOL and T.BIL and increased liver weight and enlarged hepatocytes microscopically in rats given nefiracetam p.o. for 90 days (Jindo et al., 1994).

Almost all of these compounds induced drug-metabolizing enzymes, and by dosing with these compounds, increased liver weight and enlarged hepatocytes were always observed in the animals, but there were no effects on blood biochemistry. Occasional and slight changes in blood biochemistry were considered to be due to other effects except enzyme induction. Since CHOL changes in dogs with estrus, the values obtained at estrus should be evaluated with care.

\section{Appearance of intra-cellular eosinophilic body}

In a female dog given compound M-4 p.o. for 28 days, there were no abnormal changes in blood biochemical parameters, but microscopically, round eosinophilic bodies were observed in some hepatocytes (Photo. 19). Also one to several eosinophilic bodies were present in the cell. Electron microscopically, the bodies were giant mitochondria and the size of a large one was similar to the nuclear size of the cells (Photo. 20). Proliferation of the endoplasmic reticulum was observed as another change.

In other reports, these changes were spontaneous in dogs (Harleman et al., 1987: Ghadially, 1988).

\section{Summary}

The toxicological correlation between blood biochemical parameters and liver histopathological findings was investigated. The expected pharmacological effects of the compounds studied in our laboratories are summarized in Table 11 , and blood biochemical parameters and their accumulated values in Tables 12 and 13 .

1) In hepatocytic injury, GPT and GOT increased in rats and dogs with good correla- tion to the severity of hepatocytic necrosis. However, GPT occasionally was not increased by some kinds of compounds, though hepatocytic necrosis was observed, and since GOT was present in other organs (cardiac muscle, skeletal muscle and kidney) except the liver, injury to these organs should be examined when the enzyme increases. ALP and LDH increased mostly in dogs with hepatocytic necrosis.

2) In cholestasis, increases in ALP, $\gamma$-GTP, T.BIL and BSP retention rates in dogs correlated relatively well with the incidence of cholestasis. In dogs, cholestasis was observed more frequently than other types of hepatic injuries.

3) In mixed types of hepatic injury, increases in GPT, GOT and ALP in rats and dogs and increases in $\gamma$-GTP and BSP retention rates in dogs correlated with the histopathological findings.

4) Steatosis was observed frequently in the same liver with hepatocytic injury, and CHOL and TRIG decreased in common in rats and dogs when the change was independently observed.

5) In accumulation-type hepatic injury, blood biochemical parameters and their values varied with the accumulated materials (autolysosomes, microbodies and test compounds) and sites of accumulation (intra-hepatocytes and bile capillaries).

6) In sinusoidal cell injury and others, some kinds of blood biochemical parameters were changed but there was no specific correlation with histopathological findings.

\section{REFERENCES}

Abernathy, C.O., Zimmerman, H.J., Ishak,K.G., Utili, R. and Gillespie, J. (1992): Druginduced cholestasis in the perfused rat liver and its reversal by tauroursodeoxycholate: An ultrastructural study. Proc. Soc. Exp. Biol. Med., 199, 54-58

Bouwens, L., Marinelli, A., Kuppen, P.J.K., Eggermont, A.M.M., Van De Velde, C.J.H. and Wisse, E. (1990): Electron microscopic observations on the accumulation of large granular lymphocytes (Pit cells) and 
Kupffer cells in the liver of rats treated with continuous infusion of interleukin 2 . Hepatology, 12 1365-1370

Carakostas, M.C., Gossett, K.A., Church, G.E. and Cleghorn B.L. (1986): Evaluating toxin-induced hepatic injury in rats by laboratory results and discriminant analysis. Vet. Pathol., 23, 264-269

Carakostas, M.C. and Banerjee, A.K. (1990): Interpreting rodent clinical laboratory data in safety assessment studies: biological and analytical components of variation. Fundam. Appl. Toxicol., 15, 744-753

Cohen, A.J. (1981): Review of the hepatic response to hypolipidaemic drugs in rodents and assessment of its toxicological significance to man. Fd. Cosmet. Toxicol., 19, 585-605

Cotariu, D., Reif, R., Zaidman, J.L. and Evans, S. (1987): Biological and morphological changes induced by sodium valproate in rat liver. Pharmacol. \& Toxicol., 60, 235-236

Dhami, M.S.I., Drangova, R., Farkas, R., Balazs, T and Feuer, G. (1979): Decreased aminotransferase activity of serum and various tissues in the rat after cefazolin treatment. Clin. Chem., 25, 1263-1266

Dooley, J.F. (1979): The role of clinical chemistry in chemical and drug safety evaluation by use of laboratory animals. Clin. Chem., 25, 345-347

Drew, R. and Priestly, B.G. (1976): Microsomal drug metabolism during $\alpha$-naphthylisothiocyanate-induced cholestasis. Toxicol. Appl. Pharmacol., 35, 491-499

Eacho, P.I., Foxworthy, P.S., Johnson, W.D. and Van Lier, R.B.L. (1985): Characterization of liver enlargement induced by compound LY171883 in rats. Fundam. Appl. Toxicol., 5, 794-803

Eacho, P.I., Foxworthy, P.S., Johnson, W.D., Hoover, D.M. and White, S.L. (1986): Hepatic peroxisomal changes induced by a tetrazole-substituted alkoxyacetophenone in rats and comparison with other species. Toxicol. Appl. Pharmcol., 83, 430-437

Estler, C.J. and Böcker, R. (1980): Role of sex and age in the tetracycline-induced hepatic steatosis. 1. Comparative study on the effect of rolitetracycline on some parame- ters of hepatic lipid metabolism in male and female mice. Toxicol. Appl. Pharmacol., 54, 508-513

Feldman, D., Swarm, R.L. and Becker, J. (1980): Elimination of excess smooth endoplasmic reticulum after phenobarbital administration. J. Histochem. Cytochem., 28, 997-1006

Fitzgerald, J.E., Petrere, J.A., McGuire, E.J. and De La Iglesia, F.A. (1986): Preclinical toxicology studies with the lipid-regulating agent gemcadiol. Fundam. Appl. Toxicol., 6, 520-531

Francavilla, A., Makowka, L., Polimeno, L., Barone, M., Demetris, J., Guglielmi, F.W., Ambrosino, G., Van Thiel, D.H. and Starzl, T.E. (1988): A novel model of acute hepatic failure in dogs with implications for transplantation research. Transplant. Proc., 20 (Suppl. 1), 713-715

Francavilla, A., Makowka, L., Polimeno, L., Barone, M., Demetris, J., Prelich, J., Van Thiel, D.H. and Starzl, T.E. (1989): A dog model for acetaminophen-induced fulminant hepatic failure. Gastroenterology, 96, 470-478

Fukushima, K., Arai, M., Kohno, Y., Suwa, T. and Satoh, T. (1990): An epoxysuccinic acid derivative (Loxistatin)-induced hepatic injury in rats and hamsters. Toxicol. Appl. Pharmacol., 105, 1-12

Ghadially, F.N. (1988): Mitochondria In: Ultrastructural Pathology of the Cell and Matrix. 3rd Ed vol. 1, pp.191-328, Butterworths, London.

Gray, J.E., Purmalis, A., Purmalis, B. and Mathews, J. (1971): Ultrastructural studies of the hepatic changes brought about by clindamycin and erythromycin in animals. Toxicol. Appl. Pharmacol., 19, 217-233

Gray, J.E., Weaver, R.N., Skinner, P., Mathews, J., Day, C.E. and Stern, K. (1974): Effects of tetracycline on ultrastructure and lipoprotein secretion in the rat hepatocyte. Toxicol. Appl. Pharmacol., 30, 317-332

Harleman, J.H., Suter, J. and Fischer, M. (1987): Intracytoplasmic eosinophilic inclusion bodies in the liver of beagle dogs. Lab. Animal Sci., 37, 229-231

Hayashi, Y., Morimoto, K. and Maekawa, A. 
(1985): Drug-induced lipidosis: Tissue accumulation and toxicity of drugs. Toxicology Forum, 8, 468-479

Hirakawa, K., Unno, T., Ogino, F., Takebe, H., Iino, T. and Nose, T. (1982): 1-month subacute oral toxicity study of KB-944, a new calcium antagonist, in rats. Arzneim. Forsch./Drug Res., 32, 1071-1077

Hruban, Z. (1984): Pulmonary and generalized lysosomal storage induced by amphiphilic drugs. Envirn. Health Perspect., 55, 53-76

Ishiyama, H., Ogino, K., Shimomura, Y., Kanbe, T. and Hobara, T. (1990): Hepatotoxicity of diethyldithiocarbamate in rats. Pharmacol. \& Toxicol., 67, 426-430

Jindo, T., Shimizu, Y., Kato, M. and Takayama, S. (1994): Thirteen-week oral toxicity study of the new cognition-enhancing agent nefiracetam in rats. Arzneim. Forsch./Drug Res., 44, 214-216

Kakishita, T., Aoki, Y., Ota, T., Tanaka, M., Kato, Y. and Otani, G. (1978): Safety studies of prazepam (K-373): Acute and subacute toxicity studies of prazepam in dogs. Ôyô Yakuri, 15, 759-775

Kanel, G.C. and Korula, J. (1992): In: Atlas of Liver Pathology, WB Saunders, Philadelphia.

Kesterson, J.W., Granneman, G.R. and Machinist, J.M. (1984): The hepatotoxicity of valpronic acid and its metabolites in rats. 1. Toxicologic, biochemical and histopathologic studies. Hepatology, 4, 1143-1152

Klatskin, G. and Conn, H.O. (1993): In: Histopathology of the Liver, vol. 1, Oxford Univ. Press, New York.

Knights, K.M., Gourlag, G.K., Hall, P.M., Adams, J.F. and Cousins, M.J. (1987): Halothane hepatitis in an animal model; time course of hepatic damage. Br. J. Exp. Path., 68, 613-624

Kobayashi, F., Matsuura, M., Hasegawa, N., Yoshizaki, T. and Harada, Y. (1980): Subacute toxicity of 6059-S in dogs. Chemotherapy, 28 (S-7), 1029-1071

Kondo, K. and Makita, T. (1996): Ultrastructural observation of changes in (Hepatic) peroxisomes by 3 to 90 days administration of bezafibrate in male rats. J. Vet. Med. Sci., 58, 743-748
Kostrubsky, V.E., Wood, S.G., Bush, M.D., Szakacs, J., Bement, W.J., Sinclair, P.R., Jeffery, E.H. and Sinclair, J.F. (1995): Acute hepatotoxicity of acetaminophen in rats treated with ethanol plus isopentanol. Biochem. Pharmacol., 50, 1743-1748

Krell, H., Metz, J., Jaeschke, H., H ke, H. and Pfaff, E. (1987): Drug-induced intrahepatic cholestasis; characterization of different pathomechanisms. Arch. Toxicol., 60, 124-130

Lake, B.G. and Gray, T.J.B. (1985): Species differences in hepatic peroxisome proliferation. Biochem. Soc. Trans., 13, 859-861

Lake, B.G., Evans, J.G., Gray, T.J.B., K r si, S.A. and North, C.J. (1989): Comparative studies on nafenopin-induced hepatic peroxisome proliferation in the rat, Syrian hamster, guinea pig and marmoset. Toxicol. Appl. Pharmacol., 99, 148-160

Leissing, N., Izzo, R. and Sargent, H. (1985): Variance estimates and individuality ratios of 25 serum constituents in beagles. Clin. Chem., 31, 83-86

Leonard, T.B., Neptun, D.A. and Popp, J.A. (1984): Serum gamma glutamyl transferase as a specific indicator of bile duct lesions in the rat liver. Am. J. Pathol., 116, 262269

Matsubara, T. and Touchi, A. (1979): Inhibitory action of cefamandole on glutamic pyruvic transaminase activity in rats. Chemotherapy, 27 (S-5), 740-748

Orentreich, N. and Berger, R.A. (1965): Liver function studies. Arch. Intern. Med., 115, 124-127

Owen, G., Smith, T.H.F. and Agersborg, H.P.K. (1970): Toxicity of some benzodiazepine compounds with CNS activity. Toxicol. Appl. Pharmacol., 16, 556-570

Panella, C., Makowka, L., Barone, M., Polimeno, L., Rizzi, S., Demetris, J., Bell, S., Guglielmi, F.W., Prelich, J.G., Van Thiel, D.H., Starzl, T.E. and Francavilla, A. (1990): Effect of ranitidine on acetaminophen-induced hepatotoxicity in dogs. Digestive Dis. Sciences, 35, 385-391

Plummer, J.L., Hall, P.M., Cousins, M.J., Bastin, F.N. and Ilsleg, A.H. (1983): Hepatic injury in rats due to prolonged sub-anaesthetic 
halothane exposure. Acta Pharmacol. et Toxicol., 53, 16-22

Plummer, J.L., Hall, P.M., Jenner, M.A., Ilsley, A.H. and Cousins, M.J. (1985): Hepatic and renal effects of prolonged exposure of rats to 50 p.p.m. methoxyflurane. Acta Pharmacol. et Toxicol., 57, 176-183

Popper, H., Rubin, E., Gardiol, D., Schaffner, F. and Paronetto, F. (1965): Drug-induced liver disease. Arch. Intern. Med., 115, 128136

Redmond, N.I., Witschi, H. and Plaa, G.L. (1971): Effect of actinomycin D, ethionine and cycloheximide on $\alpha$-naphthylisothiocyanate-induced hyperbilirubinemia and cholestasis in rats. Pharmacologist, 13, 288

Roberts, S.M., Harbison, R.D., Roth, L and James, R.C. (1994): Methylphenidateinduced hepatotoxicity in mice and its potentiation by $\beta$-adrenergic agonist drugs. Life Sciences, 55, 269-281

Ryffel, B., Donatsch, P., Madörin, M., Matter, B.E., Ruttimann, K., Schön, H., Stoll, R. and Wilson, J. (1983): Toxicological evaluation of cyclosporin A. Arch. Toxicol., 53, 107-141

Shauer, B.A., Lukacs, L. and Zimmerman, H.J. (1974): Biochemical indices of tetracycline hepatic injury in rats. Proc. Soc. Exp. Biol. Med., 147, 868-872

Smetana, H.F. (1963): Histopathology of druginduced liver disease. Ann. N.Y. Acad. Sci., 104, 825-846

Stäubli, W., Hess, R. and Weibel, E.R. (1969): Correlated morphometric and biochemical studies on the liver cell; II. Effects of phenobarbital on rat hepatocytes. J. Cell Biology, 42, 92-112

Sugawara, T., Yoshida, M., Shimoda, K., Takada, S., Miyamoto, M., Nomura, M and Kato, M. (1996): One-month oral toxicity study of the new quinolone antibacterial agent (s)-10-[(s)-(8-amino-6-azaspiro[3,4] octan-6-yl)]-9-fluoro-2,3-dihydro-3methyl-7-oxo-7H-pyrido[1,2,3-de][1,4] benzoxazine-6-carboxylic acid hemihydrate in rats and cynomolgus monkeys. Arzneim. Forsch/Drug Res., 46, 705-710

Suzuki, H., Yoshida, T., Ozaki, h., Miki, H. and Shiobara, Y. (1983): Twenty-six weeks intravenous toxicity study of cefpiramide in cynomolgus monkeys. Jap. J. Antibiotics, 36, 1377-1410

Tsuchiya, K., Tanaka, N., Kurashina, H. and Orita, S. (1976): Nephro- and hepato-toxicity of cephacetrile compared with those of other cephalosporins. Chemotherapy, 24, 94-105

Uchiyama, T., Tokoi, K. and Deki, T. (1985): Successive changes in the blood composition of the experimental normal beagle dogs accompanied with age. Exp. Anim., 34, 367-377

Unno, T., Ogino, F., Takebe, H., Iino, T., Hirakawa, K. and Nose, T. (1980):Subacute oral toxicity of 7-chloro-1-cyclopropylmethyl-1-3-dihydro-5-(2-fluorophenyl) 2H-1-4-benzodiazepin-2-one (KB-509) in dogs. Ôyô Yakuri, 20, 1105-1140

Whitehouse, L.W., Menzies, A., Mueller, R. and Pontefract, R. (1994): Ketokonazoleinduced hepatic phospholipidosis in the mouse and its association with de-N-acetyl ketoconazole. Toxicology, 94, 81-95

Wolford, S.T., Schroer, R.A., Gohs, F.X., Gallo, P.P., Brodeck, M., Falk, H.B. and Ruhren, R. (1986): Reference range data base for serum chemistry and hematology values in laboratory animals. J. Toxicol. Envirn. Health, 18, 161-188

Yang, C., Gemzik, B., Ewing, P., Pratt, M., Friedman, M., Cusick, P., Krasula, R. and Patterson, R. (1995): One-month oral toxicity studies of a protease inhibitor (ABT987) in rats and dogs. Antiviral Research, 26, A286

Zimmerman, H.J. and Ishak, K.G. (1979): Hepatic injury due to drugs and toxins. In Pathology of the Liver. (MacSween, R.N.M., et al., eds.) pp335-386, Churchill Livingstone, Edinburgh. 